\title{
Higher Triglyceride and Normal HDL-C Concentrations, the Triglyceride/HDL-C Concentration Ratios $\geq 3.5$, and Insulin Resistance as Potential Predictors of Developing Higher Paroxetine Concentrations and Suicide in the Early Months of Medication
}

\author{
Eiko K. Nakagawa \\ 1-6-10, Izumisano, Osaka, 598-0072, Japan, \\ Email: eknjcn [AT] jcom.zaq.ne.jp
}

\begin{abstract}
Background: There are several reported results. Hazard ratios for suicide tended to increase with dose for selective serotonin reuptake inhibitors (SSRIs). The suicide rate in the first three months following initiation of paroxetine exposure was 799 per 100,000 person-years, while, annual suicide rates for depression and anxiety were 81.8 and 76.7, respectively. SSRIs serum concentrations were significantly associated with increases of triglyceride (TG) levels. SSRIs inhibited insulin signaling and beta cell function by a dose-dependent manner.
\end{abstract}

Objective: Based on symptoms and blood lipid levels indicated by a young patient who committed suicide, my objective is to propose that higher TG concentrations above the normal range, normal high-density lipoprotein cholesterol $(H D L-C)$ concentrations, and the TG/HDL-C concentration ( $\mathrm{mg} / \mathrm{dL})$ ratios $\geq 3.5$ to estimate insulin resistance are potentially useful in identifying individuals who are developing higher paroxetine concentrations.

Methods: The glucose and lipid levels in the blood examination which was performed in an emergency hospital to where the patient was delivered by ambulance after his abnormal behaviors on the $14^{\text {th }}$ day after the start of paroxetine treatment, were used for calculation and examination. Fasting TG levels were estimated by calculating TG values (TG-Cal) using the measured value of TG and a formula reported by Hitze et al., or the measured values of total cholesterol (TC), HDL-C, and low-density lipoprotein cholesterol (LDL-C), and nine formulas referred and reported by Dansethakul et al. Paroxetine levels in the patient's serum were estimated by calculation using the regression coefficient of TG $46.49 \mathrm{mg} / \mathrm{dL}$, with which the paroxetine serum concentration $75 \mathrm{ng} / \mathrm{mL}$ was associated in the results reported by Fjukstad et al.

Results: The 20-year-old patient free of recent suicidal ideation developed intense violent suicidal preoccupation, and exhibited abnormal behaviors in the first 41 days after the start of paroxetine treatment $10 \mathrm{mg}$ twice daily. He sent emails with advanced notice of suicide to his friend on the $7^{\text {th }}, 17^{\text {th }}$, and $18^{\text {th }}$ days, drank alcohol alone and exhibited abnormal behaviors in a market place around noon, blacked out, and was ambulanced to the emergency hospital on the $14^{\text {th }}$ day. Finally, he carried out suicide on the $41^{\text {st }}$ day after three days of abrupt discontinuation of paroxetine. He never exhibited these abnormal behaviors before paroxetine exposure.

The levels of glucose, TG, TC, HDL-C, and LDL-C measured in the blood examination at 15:56 on the $14^{\text {th }}$ day after the start of paroxetine treatment were 111, 498, 185, 53, and $92 \mathrm{mg} / \mathrm{dL}$, respectively. The levels of TC, HDL-C, and LDL-C were in the normal ranges, respectively, probably suggesting metabolic normality of the patient before paroxetine exposure. In order to estimate the fasting TG level, TG-Cal values were calculated to be 278, 200, 258, 240, $268,272,310,308,311$, and $250 \mathrm{mg} / \mathrm{dL}$ in the range of $200-311 \mathrm{mg} / \mathrm{dL}$ beyond the normal range of TG $50-150$ $\mathrm{mg} / \mathrm{dL}$. TG-Cal/HDL-C ratios were also calculated to be in the range of $3.8-5.9$ (200/53 - 311/53), probably suggesting that the patient was in the stage of insulin resistance development. The paroxetine level in the patient's serum was estimated to be in the range of $161-387 \mathrm{ng} / \mathrm{mL}$ by calculation using formulas 75(TG-Cal - 71)/46.49, 75(TG-Cal - 92.25)/46.49, and 75(TG-Cal - 100)/46.49, on the assumption that the patient's TG levels before paroxetine exposure were $71,92.25$, and $100 \mathrm{mg} / \mathrm{dL}$, respectively. The paroxetine concentrations in the range of 161 $387 \mathrm{ng} / \mathrm{mL}$ were much higher than the therapeutic reference range $30-120 \mathrm{ng} / \mathrm{mL}$.

Conclusions: The above results probably suggest that paroxetine exposure, higher TG concentration, higher paroxetine concentration, and suicide coincided in the patient. Follow-up measurements of TG and HDL-C concentrations and the TG/HDL-C ratios have a potential to predict and prevent suicides in the early months of paroxetine exposure. 
Keywords - triglyceride and HDL-C concentrations and ratios, paroxetine concentration, predict suicide, duty to warn and confidentiality

\section{INTRODUCTION}

Paroxetine (Paxil; GlaxoSmithKline plc (GSK), London, UK) was first listed National Health Insurance and put on the market in 2000 in Japan. Paroxetine is one of the antidepressants and belongs to SSRIs which are used in the treatment of major depressive disorder (MDD) and anxiety disorders [1]. However, the use of antidepressant medication in children and adolescents has been controversial because of concerns about efficacy, and higher risk of adverse events and suicide in the young population. The package insert of paroxetine includes the warning sentences titled "Suicidality and Antidepressant Drugs" and "Antidepressants increased the risk compared to placebo of suicidal thinking and behavior (suicidality) in children, adolescents, and young adults in short-term studies of MDD and other psychiatric disorders. Anyone considering the use of paroxetine or any other antidepressant in a child, adolescent, or young adult must balance this risk with the clinical need. Families and caregivers should be advised of the need for close observation and communication with the prescriber." [1]. Noury et al. reanalyzed Study 329, and found that there were 211 adverse events in the paroxetine group, 147 on imipramine, and 100 on placebo. The taper phase of paroxetine had a higher proportion of severe adverse events per week of exposure than the acute phase, with the continuation phase having the fewest events [2]. Two simultaneous increases were observed both in youth suicide rates and antidepressant sales amounts in Japan, 2002 - 2009. A possible link was suggested between both the increases of youth suicides and uses of antidepressants, especially SSRIs such as paroxetine. While significant decreases of suicide rates coincided in older generations in the same period. The changes in suicide rates were strongly age-specific [3]. Lucire and Crotty suggested that the key lies in understanding the interplay between the subject's CYP450 genotype, substrate drugs and doses, coprescribed inhibitors and inducers and the age of the subject. The subject's young age would have placed him in the higher risk category for serious adversity on antidepressants [4].

Hiemke et al. reported that the therapeutic reference range for paroxetine was $30-120 \mathrm{ng} / \mathrm{mL}$, and the laboratory alert level was $240 \mathrm{ng} / \mathrm{mL}$ [5]. Tomita et al. investigated the relationship between plasma concentrations of paroxetine and the therapeutic effect of the drug, and reported that the therapeutic reference range for patients with MDD $(\mathrm{N}=120)$ was the $20-60 \mathrm{ng} / \mathrm{mL}$ plasma concentration range of paroxetine, in which the Montgomery-Asberg Depression Rating Scale (MADRS) responder rates were around 90 to $100 \%$, while, in the $60-120 \mathrm{ng} / \mathrm{mL}$ range, the MADRS responder rates decreased to around 50 to $60 \%$ [6]. Kreilgaard et al. reported that therapeutically effective 5-hydroxytryptamine (5HT; serotonin) transporter (SERT) occupancy for paroxetine in depressed patients was approximately $80 \%$, and the corresponding paroxetine plasma concentration was $21-95 \mathrm{ng} / \mathrm{mL}$ [7]. The serotonin-potentiated syndrome was induced by administering drugs that increase extracellular serotonin levels, and the serotonin-potentiated syndrome scores increased in the range of 80 to100\% for SERT occupancy by paroxetine [7]. Hegerl et al. reported that the serotonin syndrome score was positively related to paroxetine plasma levels [8]. The low serotonin syndrome scores $(0-3)$ corresponded to the paroxetine plasma level $60.9 \pm 34.5 \mathrm{ng} / \mathrm{mL}$, while, the high serotonin syndrome scores $(4-9)$ corresponded to the paroxetine plasma level $106.5 \pm 90.1 \mathrm{ng} / \mathrm{mL}$ [8]. Coupland et al. examined antidepressant use and risk of suicide in the cohort study $(\mathrm{N}=238,963)$, and reported that the hazard ratios for suicide tended to increase with dose for SSRIs [9]. In antidepressant drugs, paroxetine risk for suicide was highest among the five SSRIs [9]. These results suggest the association between higher paroxetine concentrations and harmful outcomes including suicide and other adverse events.

Valenstein et al. examined differential risks of suicide death in a large cohort of veterans $(\mathrm{N}=502,179)$ with depression diagnoses who had a new start of any of the seven most commonly prescribed antidepressant medications in the Department of Veterans Affairs between 1999 and 2004, and reported that the suicide rates for new users of citalopram $(\mathrm{N}=131,283)$, bupropion $(\mathrm{N}=54,692)$, fluoxetine $(\mathrm{N}=70,499)$, venlafaxine $(\mathrm{N}=21,976)$, sertraline $(\mathrm{N}=$ $135,655)$, paroxetine $(\mathrm{N}=66,927)$, and mirtazapine $(\mathrm{N}=21,147)$ by the time period $0-90$ days following initiation were $633,189,451,698,515,799$, and 456 per 100,000 person-years, respectively [10, 11]. Their model analyses indicated that sertraline and fluoxetine had lower risks for suicide death than paroxetine [10] in the veterans with similar characteristics reported by Kim et al. [11]. While, Ilgen et al. reported that annual suicide rates for veterans with depression $(\mathrm{N}=477,489)$ and anxiety $(\mathrm{N}=240,905)$ were 81.8 and 76.7 per 100,000 person-years, respectively [12]. These results indicate that the suicide rate increased approximately ten times in the first three months following initiation of paroxetine exposure, and probably suggest that about $90 \%$ of suicides was associated with paroxetine in the period.

Beyazyüz et al. examined the relationship between SSRIs and metabolic syndrome abnormalities in drug-naive first episode patients with generalized anxiety disorder aged 20 - 41 years without any metabolic or psychiatric comorbidity. They reported that there were significant increases in the parameters of weight, BMI, waist circumference, fasting 
glucose, TG, TC, and LDL-C after 16 weeks of paroxetine treatment $(\mathrm{N}=20)$ [13]. In the paroxetine group, the most significant increases were observed in the parameters among the five SSRIs examined [13]. Fjukstad et al. used the data from a cross-sectional study on 1301 patients with schizophrenia or bipolar disorder, of whom 280 were treated with SSRIs, and reported that an SSRI serum concentration in the middle of the reference interval was associated with an increase of the TG level by $46.49 \mathrm{mg} / \mathrm{dL}$ (95\% confidence interval $(\mathrm{CI}) 26.53-66.46 \mathrm{mg} / \mathrm{dL}, P<0.001$ ), the TC level by $14.56 \mathrm{mg} / \mathrm{dL}$ (CI $5.27-23.85 \mathrm{mg} / \mathrm{dL}, P=0.002)$, the LDL-C level by $8.50 \mathrm{mg} / \mathrm{dL}$ (CI $0.22-16.77 \mathrm{mg} / \mathrm{dL}, P=0.044)$, and the occurrence of the metabolic syndrome by a factor of 2.10 (CI $1.21-3.62, P=0.008)$, on the condition that treatment duration was not taken into consideration [14]. The paroxetine serum concentration of the middle of the reference interval was $75 \mathrm{ng} / \mathrm{mL}$ and the reference interval was $30-120 \mathrm{ng} / \mathrm{mL}$ [14]. In the serum levels of TG, the association was statistically most significant $(P<0.001)$ among the outcome variables, when related to the SSRI serum concentration [14].

Levkovitz et al. reported that SSRIs paroxetine and sertraline induced cellular insulin resistance by activation of insulin receptor substrate (IRS)-1 kinases and inhibited the insulin-stimulated Tyr phosphorylation of IRS-1 [15]. Isaac et al. reported that SSRIs paroxetine, fluoxetine, or sertraline inhibited insulin secretion and action in pancreatic $\beta$ cells. SSRIs paroxetine, fluoxetine, or sertraline inhibited both insulin-induced Tyr phosphorylation of insulin receptor substrate (IRS)-2 protein and the activation of its downstream targets in a dose-dependent manner [16]. They demonstrated that SSRIs are potential inducers of insulin resistance, acting by directly inhibiting the insulin signaling cascade in $\beta$ cells [16]. These results indicate a link between paroxetine exposure and metabolic abnormalities including insulin resistance.

Insulin resistance was assessed using the homeostasis model assessment (HOMA) system described by Matthews et al. [17] with the formula (insulin $(\mu \mathrm{U} / \mathrm{mL}) \times$ plasma glucose $(\mathrm{mg} / \mathrm{dL}) / 405)$. Fujii et al. reported the parameters of fasting glucose and HOMA-IR etc. for the subjects classified as normal glucose tolerant (NGT) $(\mathrm{N}=33)$, impaired glucose tolerant (IGT) $(\mathrm{N}=71)$, and diabetes $(\mathrm{N}=7)$ [18]. The parameters of fasting glucose $(\mathrm{FG})$ were $93.8 \pm 1.6 \mathrm{mg} / \mathrm{dL}$ for NGT, $109.4 \pm 1.5 \mathrm{mg} / \mathrm{dL}$ for IGT, and $141.6 \pm 4.8 \mathrm{mg} / \mathrm{dL}$ for diabetes subjects [18]. The parameters of HOMA-IR were $1.5 \pm 0.2$ for NGT, $2.7 \pm 0.3$ for IGT, and $4.1 \pm 1.5$ for diabetes subjects [18]. Because HOMA-IR $\geq 2.5$ is a considerable indicator of insulin resistance for Japanese subjects as reported by Yamada et al. [19], it is suggested that the majority of the IGT subjects had insulin resistance and moderately high level of FG $109.4 \pm 1.5 \mathrm{mg} / \mathrm{dL}$. Tabák et al. showed the changes in glucose concentrations, insulin sensitivity, and insulin secretion as much as $3-6$ years before diagnosis of diabetes [20]. The IGT subjects with mean FG $109.4 \pm 1.5 \mathrm{mg} / \mathrm{dL}$ reported by Fujii et al. [18] seem to be destined to diabetes in a few years based on the graph for FG trajectory before diagnosis of diabetes by Tabák et al.[20]. These results suggest that it generally takes several years to migrate from NGT to IGT, and IGT to diabetes.

Reaven proposed that the TG/HDL-C concentration $(\mathrm{mg} / \mathrm{dL})$ ratio $>3.0$ can be useful in identifying individuals who are insulin resistant [21]. McLaughlin et al. reported the TG/HDL-C concentration ratio $\geq 3.5$ provides a simple means of identifying insulin-resistant [22]. Salazar et al. reported that using the TG/HDL-C concentration ratios $>2.5$ in women (N $=1,102)$ and $>3.5$ in men $(\mathrm{N}=464)$ of primarily European ancestry identified subgroups of men and women that were comparable in terms of insulin resistance and associated cardio-metabolic risk [23]. Murguía-Romero et al. reported that the same TG/HDL-C cut-points can identify apparently healthy Mexican-Mestizo individuals who are insulin resistant [24]. Shin et al. evaluated the data of Korean adults $(\mathrm{N}=32,875,039)$, and reported that the cutoff value of the TG/HDL$\mathrm{C}$ ratio for the fourth upper quartile was $\geq 3.52$ [25]. Samant et al. showed the positive correlation between HOMA-IR and TG/HDL-C ratio [26]. HOMA-IR was $2.23 \pm 0.69$, and TG/HDL-C ratio was $2.4653 \pm 0.2094$ in the control group $(\mathrm{N}=50)$, while, HOMA-IR was $6.14 \pm 0.09$, and TG/HDL-C ratio was $4.554 \pm 0.152$ in the metabolic syndrome group $(\mathrm{N}=60)$ [26]. Ray et al. also reported that the TG/HDL-C ratio was significantly correlated with HOMA-IR in the study to assess whether serum lipoprotein ratios could predict insulin resistance in non-diabetic acute coronary syndrome patients $(\mathrm{N}=90)$ [27]. HOMA-IR 2.5 corresponded to the TG/HDL-C ratio 3.2 in the scatter diagram showing positive correlation between them [26]. Based on these results, it seems likely that the TG/HDL-C concentration (mg/dL) ratios $\geq$ 3.5 are more certainly useful in identifying individuals who are insulin resistant.

Kathiresan et al. reported the tendency between the TG level increase and HDL-C level decrease obtained in men (N $=1404$, age $50 \pm 10 \mathrm{y}$ ) according to the number of metabolic abnormalities (metabolic syndrome (MetSyn) features) [28]. The levels of TG $71 \pm 3 \mathrm{mg} / \mathrm{dL}$ and HDL-C $52 \pm 1 \mathrm{mg} / \mathrm{dL}$ were presented in the group without MetSyn $(\mathrm{N}=286)$, while, the levels of TG $231 \pm 10 \mathrm{mg} / \mathrm{dL}$ and HDL-C $32 \pm 2 \mathrm{mg} / \mathrm{dL}$ were presented in the group with five MetSyn components $(\mathrm{N}=30)$ [28]. The levels of LDL-C $127 \pm 2$ and $136 \pm 6 \mathrm{mg} / \mathrm{dL}$ were presented in the groups with the MetSyn component number 0 and 5, respectively [28]. Lewis et al. showed, in a series of experiments, that the hypertriglyceridemia of insulin resistant states results in modification of HDL composition, including but not limited to TG enrichment and cholesteryl ester depletion of the HDL particles, which, in the presence of the enzyme hepatic lipase, results in loss of apoA-I from the circulation and ultimately a lowering of HDL concentration [29]. Lamarche et al. investigated the effect of TG enrichment of HDL on the clearance of HDL-associated apo A-I in humans $(\mathrm{N}=6)$, and 
reported that a five-hour intra-lipid infusion with a synthetic TG emulsion resulted in a 2.1 -fold increase in the TG content of HDL, and apo A-I in TG-enriched HDL was cleared 26\% more rapidly than apo A-I in fasting HDL, that is, TG enrichment of HDL increased the fractional catabolic rate (FCR) of apo A-I by an average of $26 \%(0.025 \pm 0.010 \mathrm{vs}$. $0.020 \pm 0.009 / \mathrm{h}$ ) compared with fasting HDL [30]. Greene et al. reported that the increase of TG content of HDL from $14.8 \%$ to $28.5 \%$ was obtained by the $24 \mathrm{~h}$-incubation of HDL with CETP and VLDL [31]. Vega et al. reported that FCRs averaged $0.256 \pm 0.019$ and $0.254 \pm 0.017$ pools/day, for free apo-AI and HDL apo-AI, respectively [32]. Mean residence time of apo A-I on fasting HDL calculated from the FCR obtained by Lamarche et al. averaged 2.3 days, while, the threeto five-day plasma residence times were reported by Vega et al. [32], Gingsberg et al. [33], and Rader et al. [34]. While, Gingsberg et al. reported that production rates (PRs) for HDL apo A-I were similar in all subjects with normal TG HDL $(\mathrm{N}=4)$, and hyper TG - low HDL $(\mathrm{N}=9)$, and normal $\mathrm{TG}$ - low HDL $(\mathrm{N}=9)$ [33]. These results probably suggest that at least several days to weeks or months are needed both for the TG enrichment of HDL and the lowering of HDL concentration after the onset of the hypertriglyceridemia of insulin resistant states.

It is known that TG levels raise in response to dietary intake. Franceschini et al. reported the effects of the two test meals with or without alcohol to induce triglyceridaemia [35]. After ethanol plus fat, TG levels increased rapidly in all subjects (nine healthy normolipidaemic volunteers aged $18-24$ years with TC and TG ranges, $143-214 \mathrm{mg} / \mathrm{dL}$ and $56-$ $122 \mathrm{mg} / \mathrm{dL}$, respectively), reaching the maximum value (+180\%) by increasing from the approx. mean 80 to $230 \mathrm{mg} / \mathrm{dL}$ at 4-6 h [35]. Hitze et al. compared postprandial TG response with basal TG levels, and suggested that fasting TG levels $\left(\mathrm{TG}_{\text {fasting }}\right)$ were highly correlated with the parameters of postprandial $\mathrm{TG}$ response: maximal postprandial TG levels $\left(\mathrm{TG}_{\mathrm{ppmax}}\right)(\mathrm{r}=0.89 ; \mathrm{p}<0.001)$ and TG- area under curve (TG-AUC) $(\mathrm{r}=0.93 ; \mathrm{p}<0.001)$ [36]. They reported the formula $(\mathrm{y}=0.59 \mathrm{x}-15.7)\left(\mathrm{y} \mathrm{TG}_{\text {fasting }}, \mathrm{x} \mathrm{TG}_{\mathrm{ppmax}}\right)$ [36]. While, Mora et al. reported that, except for TG, lipid concentrations differed minimally $(<5 \%)$ for fasting versus non-fasting in a prospective study of 26,330 healthy women $(19,983$ fasting; 6,347 non-fasting). Lipid concentrations median (25th to 75th percentile) (mg/dL) were 209 (185 - 236) for fasting TC, 206 (181 - 234) for non-fasting TC, 123 (102 - 146) for fasting LDL-C, 117 (97 - 140) for non-fasting LDL-C, 52 (43 62) for fasting HDL-C, and 52 (43 - 62) for non-fasting HDL-C [37]. Franceschini et al. reported that after the test meals with ethanol and fat, serum TC concentrations did not change (range $162.3-169.7 \mathrm{mg} / \mathrm{dL}$ ), and HDL-C levels decreased progressively, through $(-5 \%)$ at $4 \mathrm{~h}$, reaching a minimum $(-10 \%)$ at $8 \mathrm{~h}$, and increasing thereafter [35]. Dansethakul et al. referred and reported the formulas to calculate LDL-C based on the measured concentrations of TG, TC and HDL-C to improve the former equations, and higher correlation coefficients ( $r$ ) between LDL-Cal and LDL-Direct using their formulas were obtained than those using the Friedewald equation etc. [38, 39]. Therefore, when TC, HDL-C, and LDL-C are directly measured in non-fasting samples with or without alcohol, the formulas of Dansethakul et al. [38] are thought to be usable to calculate TG concentrations with little effect of food or alcohol.

Based on the knowledge of the results reported as above, the association was examined between the patient's suicide and paroxetine exposure.

\section{METHODS}

Suicidal thoughts and behaviors in the patient were compared between before and after paroxetine exposure. The suicide rate in the first three months following initiation of paroxetine exposure reported by Valenstein et al. [10, 11] was compared with those in depression and anxiety disorders reported by Ilgen et al. [12] to examine the effect of paroxetine exposure on suicide in the early months of medication. The fasting TG level in the patient was estimated by calculating TG-Cal values using the measured value of TG and the formula reported by Hitze et al. [36], or using the measured values of TC, HDL-C, and LDL-C, and nine formulas referred and reported by Dansethakul et al. [38]. The blood level of paroxetine in the patient's serum was estimated using ten TG-Cal values and the regression coefficient of TG 46.49 $\mathrm{mg} / \mathrm{dL}$, with which the paroxetine serum concentration $75 \mathrm{ng} / \mathrm{mL}$ was associated as reported by Fjukstad et al. [14]. The timing of appearance of insulin resistance probably developed in the patient during paroxetine exposure was investigated by comparing the TG-Cal and HDL-C levels with those reported by Kathiresan et al. [28].

\section{RESULTS AND DISCUSSION}

\subsection{Medical record review, unusual changes in behavior, and emails with advanced notice of suicide}

On May 22 $2^{\text {nd }}, 2010$, a university student Mr. A visited to a psychiatrist Dr. B for psychiatric consultation. A timeline is shown in Fig. 1. It was the first psychiatric visit for Mr. A, who was 20-year-old and lived alone for about a year in an apartment which was about $200 \mathrm{~km}$ far from his family's house. He had no history of psychiatric consultation or mental illness. Mr. A complained to Psychiatrist B by saying as follows, "When I am talking to my friend, I become nervous and that condition continues for quite a while. When I was 13 year-old in a second-year junior high school, I got trauma, because one of my classmates told that my hair whorl was bald. After that I felt uneasy when I sensed someone was watching my hair whorl from behind. I usually take a seat at the end of row in the university lecture room. When my heart races, I become clumsy. When I was 15 year-old in a senior high school, and I am now a university student, I have 
become to feel that people do not watch my hair whorl." Psychiatrist B wrote the complaints in five sentences in the medical record, and wrote "depressive reaction" as a disease name in the column for diagnosis. Psychiatrist B prescribed both Paxil (paroxetine) $10 \mathrm{mg}$ twice daily and Melex (mexazolam) $1 \mathrm{mg}$ twice daily for 7 days. The medical record was later perpetuated as evidence by attorneys.

Psychiatrist B did not balance the risk increased compared to placebo of suicidal thinking and behavior (suicidality) in children, adolescents, and young adults in short-term studies of MDD and other psychiatric disorders with the clinical need. Psychiatrist B did not base on Diagnostic and Statistical Manual of Mental Disorders 4th edition (DSM-IV) [1] to make the diagnosis. Psychiatrist B did not advise Mr. A or his family of the need of close observation and communication with the prescriber about clinical worsening, suicidality, or unusual changes in behavior, despite the warning that was clearly written in the black boxed warning message of the Paxil package insert revised version on April 2010 [1]. Psychiatrist B inadequately prescribed paroxetine "twice daily" instead of "once daily" defined as the dosing interval in the Paxil package insert [1].

On May 29 2010 (the $8^{\text {th }}$ day after the start of paroxetine treatment), Mr. A visited Psychiatrist B for the second consultation. According to the medical record, Mr. A said to Psychiatrist B, "I feel slightly better". Psychiatrist B also wrote "He shows Lüchelndezügo (smile)." in total two short sentences in the medical record, and again prescribed paroxetine $10 \mathrm{mg}$ twice daily and mexazolam $1 \mathrm{mg}$ twice daily for 14 days. In spite of the need of close observation and communication, Psychiatrist B completely ignored the warning, and left Mr. A in paroxetine exposure. In the afternoon of the same day, Mr. A met his family for the first time since May $2^{\text {nd }}$. They went to a pond for fishing, but Mr. A was not interested in fishing at all, but sat smoking a cigarette on the bank. Mr. A used to not smoke but love fishing. The family felt strange to find that Mr. A changed. Mr. A told that he consulted a psychiatrist to cure a heart-racing.

On June $4^{\text {th }}, 2010$ (the $14^{\text {th }}$ day after the start of paroxetine treatment), Mr. A was in a grocery supermarket around noon and developed unusual behaviors. He drank much alcohol alone on a bench. He ran down an escalator in the wrong direction to tumble down, and blacked out with vomiting on the basement floor. Mr. A had never taken on such unusual behaviors before paroxetine exposure. He was found by a caretaker of the building and was delivered to an emergency hospital C by ambulance. Mr. A got a blood examination at 15:56 in Hospital C. The medical record written in Hospital $\mathrm{C}$ was perpetuated as evidence. Glucose and lipid measures of the blood examination are summarized in Table 1. Mr. A's unusual behaviors were informed both to Psychiatrist B and the family by telephone from the emergency physician of Hospital C on the same day. Despite the occurrence of unusual behavior changes while taking paroxetine, Psychiatrist B did not take any proper cares at all such as tapering the dose to stop paroxetine, or advising the family of the risk and paroxetine. Not only Mr. A but also the family could not think of a possible link between current medication paroxetine and the unusual behavior changes.

On June $14^{\text {th }}, 2010$, (the $24^{\text {th }}$ day after the start of paroxetine treatment), Mr. A visited Psychiatrist B for the third and last consultation. According to the medical record, Mr. A told to Psychiatrist B, "I feel good". Psychiatrist B wrote only one sentence in the medical record, and prescribed again paroxetine $10 \mathrm{mg}$ twice daily and mexazolam $1 \mathrm{mg}$ twice daily for 14 days. Psychiatrist B did not take Mr. A's unusual behaviors on June $4^{\text {th }}$ seriously, did not taper the dose of paroxetine down to stop it, or did not warn Mr. A or his family against abrupt stopping paroxetine, despite the warning that abrupt discontinuation can lead to adverse events including suicidality as written in the package insert of Paxil [1].

On June $28^{\text {th }}, 2010$, (the $38^{\text {th }}$ day after the start of paroxetine treatment), the next day of the last dose of paroxetine, Mr. A visited another psychiatrist Dr. D, and complained by saying, "I cannot sleep. I have a difficulty in falling asleep more than 1 or 2 hours after my creeping into bed." Psychiatrist D prescribed zolpidem tartrate (Myslee) 10mg once daily before bedtime for 7 days. Psychiatrist D did not consider that abrupt discontinuation of current medication paroxetine could occur in the patient. While, Psychiatrist B should have found that abrupt discontinuation of paroxetine was going on with Mr. A on June $28^{\text {th }}$ as a result of his no visit, but Psychiatrist B did not do anything.

In the early part of April 2010, Mr. A made a friend through email exchanges with the same university student Miss E. In the middle part of April, Mr. A sent many emails to Miss E with joy. Their relationship was limited in the email exchanges. In the late part of April, Miss E told Mr. A not to send emails any more to her. Mr. A erased her personal email address to avoid sending of emails to her. During about a month from late April to late May, Mr. A did not send emails to Miss E, or no significant events happened as shown in Fig. 1. On May $2^{\text {nd }}$, 2010, Mr. A and the family talked and laughed sitting over a table in a wedding reception for the relative. Mr. A was normal without unusual behaviors.

After a few days of the start of paroxetine treatment on May 22 $2^{\text {nd }}, 2010, \mathrm{Mr}$. A restarted to send emails to Miss E by using another email address maintained by the university. On May $28^{\text {th }}$, June $7^{\text {th }}$, and June $8^{\text {th }}$, (the $7^{\text {th }}$, $17^{\text {th }}$, and $18^{\text {th }}$ days respectively after the start of paroxetine treatment), Mr. A sent three emails expressing intense violent suicidal preoccupation with advanced notice of suicide to Miss E. Mr. A had never sent such emails to Miss E or anyone before paroxetine exposure. The timeline is shown in Fig. 1. In the middle part of June, the contents of email messages were informed by phone to the family from a counselor of the university who talked with Miss E. On June $12^{\text {th }}$, the family members talked with Mr. A about the email messages. Mr. A 
talked to them that he had no thought to suicide. In the late part of June, when the family telephoned to Mr. A, he was watching the video movie the Exorcist with laughing loudly at some scenes in his apartment. He used not to watch occult films because of fear of a nightmare. The family felt anything odd and a need to see him in the near future.

On July $1^{\text {st }}, 2010$ (the $41^{\text {st }}$ day after the start of paroxetine treatment), three days after the abrupt discontinuation of paroxetine, Mr. A carried out suicide by generating hydrogen sulfide in a car. He left a suicide note to his family. Paroxetine exposure temporally coincided with the events of unusual changes in behavior, sending of emails with advanced notice of suicide, and suicide completion. The family was unaware of the suicide risk and paroxetine before the death.

\section{2 The suicide rate 799 in the first three months following initiation of paroxetine exposure reported by Valenstein et al.}

The comparison among the suicide rates, 799 by the time period $0-90$ days following the new start for paroxetine users of veterans per 100,000 person-years, 81.8 by an annual rate for veterans with depression, and 76.7 by an annual rate for veterans with anxiety reported by Valenstein et al., Kim et al., and Ilgen et al., respectively $[10,11,12]$ indicates that the suicide rate was increased by about ten times in the first three months following the new start of paroxetine exposure, and probably suggests that paroxetine enhanced suicide death by about ten times and was associated with around $90 \%$ of suicides in the period. They found the risk differences over time among seven antidepressants in the similar characteristics of patients $(\mathrm{N}=502,179)$ by the first each antidepressant prescribed [11], and reported that sertraline and fluoxetine had lower risks for suicide death than paroxetine [10]. Paroxetine showed the highest risk in the log hazard of complete suicide among seven antidepressants in the time period 0 - around 60 days [10]. The results might suggest that age and/or gene related different susceptibility and selection of patients in gene expression, enzymatic activity and inhibition of paroxetine-metabolizing enzymes including CYP2D6 [4] have become evident in the first few months. The $41^{\text {st }}$ day of the suicide of Mr. A is included in the time period.

\section{3 Metabolic normality in the last period before paroxetine exposure probably suggested by the levels of TC, HDL-C, and LDL-C measured on the $14^{\text {th }}$ day after the start of paroxetine treatment}

The blood examination was performed at 15:56 on June $4^{\text {th }}, 2010$ (the $14^{\text {th }}$ day after the start of paroxetine treatment) in Hospital $\mathrm{C}$ where Mr. A was delivered by ambulance after his heavy drinking alcohol and unusual behaviors around noon in the building of glossary super market. The levels of glucose, TG, TC, HDL-C, and LDL-C were 111, 498, 185, 53, and $92 \mathrm{mg} / \mathrm{dL}$, respectively, as summarized in Table 1 . These levels were not measured in the fasting condition. But, based on the results reported by Franceschini et al. [35] and Mora et al. [37], it is estimated that the unknown fasting levels of TC, HDL-C, and LDL-C in Mr. A differed minimally $(\leq 5 \%)$ from the non-fasting levels 185,53 , and $92 \mathrm{mg} / \mathrm{dL}$, respectively.

Murakata et al. examined the age-related changes in clinical parameters including fasting glucose, TG, HDL-C, and LDL-C in community-dwelling individuals who were recruited to a population-based cohort study (3,352 men, and 2,675 women) in Japan [40]. They reported that both the mean serum TG and LDL-C levels increased with age up to $~ 50$ years and decreased thereafter, while the mean serum HDL-C level did not correlate with age in men [40]. They reported the least-squares lines to represent the data plots $(15,639,15,627$, and 14,997 measurements for TG, HDL-C, and LDL-C, respectively) for men by the following equations; serum TG $(\mathrm{mg} / \mathrm{dL})=152.3008-0.2561 \mathrm{x}-0.0635(\mathrm{x}-52.4919)^{2}$, serum HDL-C $(\mathrm{mg} / \mathrm{dL})=55.5027+0.0241 \mathrm{x}$, and serum LDL-C $(\mathrm{mg} / \mathrm{dL})=134.9502-0.1499 \mathrm{x}-0.0254723(\mathrm{x}-$ $52.4919)^{2}$, (x, age year) [40]. By using these equations, the mean TG, HDL-C, and LDL-C levels were calculated to be 80.1, 56.0, and $105.1 \mathrm{mg} / \mathrm{dL}$ for 20-year-old men. The mean HDL-C and LDL-C levels are probably comparable to the HDL-C and LDL-C levels 53, and $92 \mathrm{mg} / \mathrm{dL}$ measured in the blood of Mr. A (Table 1).

The lipid levels in Mr. A measured after two weeks paroxetine treatment (Table 1) were compared with the corresponding levels measured before and after 16 weeks paroxetine treatment in 20 patients aged $27.5 \pm 3.1$ years without any metabolic comorbidity reported by Beyazyüz2013 et al. [13] as shown in Fig. 2. They reported that the parameters of fasting glucose increased from $92.35 \pm 11.07 \mathrm{mg} / \mathrm{dL}$ to $101.65 \pm 11.52 \mathrm{mg} / \mathrm{dL}$, TG increased from $92.25 \pm$ $19.41 \mathrm{mg} / \mathrm{dL}$ to $129.95 \pm 40.61 \mathrm{mg} / \mathrm{dL}$, TC increased from $168.85 \pm 16.97 \mathrm{mg} / \mathrm{dL}$ to $186.05 \pm 15.82 \mathrm{mg} / \mathrm{dL}$, and LDL-C increased from $90.45 \pm 22.88 \mathrm{mg} / \mathrm{dL}$ to $103.60 \pm 22.6 \mathrm{mg} / \mathrm{dL}$, while, HDL-C decreased from $54.01 \pm 4.85 \mathrm{mg} / \mathrm{dL}$ to $53.71 \pm 6.46 \mathrm{mg} / \mathrm{dL}$ after 16 weeks of paroxetine treatment [13]. The levels of TC $185 \mathrm{mg} / \mathrm{dL}$, HDL-C $53 \mathrm{mg} / \mathrm{dL}$, and LDL-C $92 \mathrm{mg} / \mathrm{dL}$ measured in Mr. A's blood (Table 1) were within the level ranges of confidence intervals reported by Beyazyüz2013 et al. for the 20 patients [13] as shown in Figs. 2d, 2e, and 2f, respectively. Further, the levels HDL-C 53 $\mathrm{mg} / \mathrm{dL}$ and LDL-C $92 \mathrm{mg} / \mathrm{dL}$ in Mr. A (Table 1) were comparable to HDL-C $52 \pm 1 \mathrm{mg} / \mathrm{dL}$ and lower than LDL-C $127 \pm$ $2 \mathrm{mg} / \mathrm{dL}$, respectively, reported for men without MetSyn features $(\mathrm{N}=286$, age $50 \pm 10$ y) by Kathiresan et al. [28]. These results probably suggest the metabolic normality of Mr. A in the last period before paroxetine exposure. 


\section{4 Hypertriglyceridemia, higher paroxetine concentration, and insulin resistance calculated and estimated using the lipid levels of TG, TC, HDL-C, and LDL-C measured on the $14^{\text {th }}$ day and ten formulas}

On the other hand, the measured levels of TG $498 \mathrm{mg} / \mathrm{dL}$ and glucose $111 \mathrm{mg} / \mathrm{dL}$ in Mr. A (Table 1) were out of the corresponding level ranges reported by Beyazyüz2013 et al. [13] as shown in Figs. 2a and 2b, respectively. Especially, the non-fasting TG level $498 \mathrm{mg} / \mathrm{dL}$ in Mr. A was much higher than the maximum TG level approx. $240 \mathrm{mg} / \mathrm{dL}$ at $6 \mathrm{~h}$ after the test meal with alcohol reported by Franceschini et al. [35]. Hitze et al. reported that fasting TG levels (TG fasting $_{\text {) }}$ were positively associated with maximal postprandial $\mathrm{TG}$ levels $\left(\mathrm{TG}_{\mathrm{ppmax}}\right)$ and TG-AUC [36]. Most of the subjects with an elevated pp TG response had elevated $\mathrm{TG}_{\text {fasting }}$ and vice versa [36]. According to the results [36] and based on the assumption that Mr. A's TG level $498 \mathrm{mg} / \mathrm{dL}$ (Table 1) was $\mathrm{TG}_{\mathrm{ppmax}}$, the $\mathrm{TG}_{\text {fasting }}$ in Mr. A was calculated (TG-Cal) to be $278 \mathrm{mg} / \mathrm{dL}$ as summarized in Table 2, using the formula reported by Hitze et al. [36] as below:

$$
\begin{aligned}
& \mathrm{y}=0.59 \mathrm{x}-15.7 \\
& \mathrm{x}=\mathrm{TG}_{\text {ppmax }}(\mathrm{mg} / \mathrm{dL})=498 \mathrm{mg} / \mathrm{dL} \\
& \mathrm{y}=\mathrm{TG}_{\text {fasting }}(\mathrm{mg} / \mathrm{dL})=278 \mathrm{mg} / \mathrm{dL}
\end{aligned}
$$

Next, the $\mathrm{TG}_{\text {fasting }}$ in Mr. A was extrapolated by calculation using the measured values of TC $185 \mathrm{mg} / \mathrm{dL}$, HDL-C 53 $\mathrm{mg} / \mathrm{dL}$, and LDL-C $92 \mathrm{mg} / \mathrm{dL}$ (Table 1) and nine formulas in the report of Dansethakul et al. [38], because TC, HDL-C, and LDL-C are relatively insulated from the influence of alcohol, fasting or non-fasting condition [35, 37]. Nine calculated TG values (TG-Cal) for Mr. A were 200, 258, 240, 268, 272, 310, 308, 311, and $250 \mathrm{mg} / \mathrm{dL}$ in the range of $200-311 \mathrm{mg} / \mathrm{dL}$ as summarized in Table 2 . The $\mathrm{TG}_{\text {fasting }}$ value $278 \mathrm{mg} / \mathrm{dL}$ calculated using the formula of Hitze et al. [36] as above was in the range of $200-311 \mathrm{mg} / \mathrm{dL}$. These ten TG-Cal values for Mr. A (Table 2) were much higher than the TG levels $92.25 \pm 19.41 \mathrm{mg} / \mathrm{dL}$ and $129.95 \pm 40.61 \mathrm{mg} / \mathrm{dL}$ in the 20 patients reported by Beyazyüz et al. [13] as shown in Fig. 2a, the mean TG level $80.1 \mathrm{mg} / \mathrm{dL}$ calculated for the 20 -year-old men using the equation reported by Murakata et al. [40] as above, and the normal range $50-150 \mathrm{mg} / \mathrm{dL}$ suggested by Hospital C (Table 1).

Fjukstad et al. reported that associations between SSRI serum concentrations and TG levels were statistically highly significant $(P<0.001)$, and an SSRI serum concentration in the middle of the reference interval was associated with an increase of the TG level by $46.49 \mathrm{mg} / \mathrm{dL}$ (CI $26.53-66.46 \mathrm{mg} / \mathrm{dL}$ ) on condition that treatment duration was not taken into consideration [14]. When the serum paroxetine concentration was $75 \mathrm{ng} / \mathrm{mL}$ (reference interval, $30-120 \mathrm{ng} / \mathrm{mL}$ ), it was associated with the $46.49 \mathrm{mg} / \mathrm{dL}$ (CI $26.53-66.46 \mathrm{mg} / \mathrm{dL}, P<0.001$ ) increase in TG level compared with the paroxetine concentration of 0 (ie, not using paroxetine) [14]. Then, the blood level of paroxetine in Mr. A's serum was estimated to be in the range of $161-387 \mathrm{ng} / \mathrm{mL}$ as summarized in Table 2, by calculation using the ten TG-Cal values (Table 2) and three formulas (a), (b), and (c) as below:

$$
\begin{aligned}
& \text { Paroxetine serum concentration in } \mathrm{Mr} \text {. A = 75(TG-Cal - 71)/46.49 } \\
& =75(\mathrm{TG}-\mathrm{Cal}-92.25) / 46.49 \\
& =75(\mathrm{TG}-\mathrm{Cal}-100) / 46.49
\end{aligned}
$$

The above formulas were based on the assumption that Mr. A's TG levels before paroxetine exposure were 71, 92.25, and $100 \mathrm{mg} / \mathrm{dL}$, respectively. The TG level $71 \pm 3 \mathrm{mg} / \mathrm{dL}$ was reported for men $(\mathrm{N}=286)$ without MetSyn features (No. of components of MetSyn 0, HDL-C $52 \pm 1 \mathrm{mg} / \mathrm{dL}$, and LDL-C $127 \pm 2 \mathrm{mg} / \mathrm{dL}$ ) by Kathiresan et al [28]. The similar TG level $73 \pm 7 \mathrm{mg} / \mathrm{dL}$ was reported for the normal subjects $(\mathrm{N}=96)$ without hyperlipidemia (HDL-C $53 \pm 13 \mathrm{mg} / \mathrm{dL}$, and LDL-C $122 \pm 28 \mathrm{mg} / \mathrm{dL}$ ) by Friedewalt et al. [39]. Both the HDL-C levels $52 \pm 1 \mathrm{mg} / \mathrm{dL}$ [28] and $53 \pm 13 \mathrm{mg} / \mathrm{dL}$ [39] are comparable to the HDL-C level $53 \mathrm{mg} / \mathrm{dL}$ measured in Mr. A's blood (Table 1). The TG level 92.25 $\pm 19.41 \mathrm{mg} / \mathrm{dL}$ was reported for the 20 patients without any metabolic comorbidities before paroxetine treatment by Beyazyüz et al. [13], as shown in Fig. 2a. The TG level $100 \mathrm{mg} / \mathrm{dL}$ was the middle of TG normal range $50-150 \mathrm{mg} / \mathrm{dL}$ as summarized in Table 1. The serum concentrations of paroxetine in the range of $161-387 \mathrm{ng} / \mathrm{mL}$ calculated and estimated for Mr. A (Table 2) as above were much higher than the therapeutic reference range for paroxetine $30-120 \mathrm{ng} / \mathrm{mL}$ reported by Heimke et al. $[5]$.

The mean paroxetine serum concentration for the 20 patients whose TG level increased from $92.25 \pm 19.41 \mathrm{mg} / \mathrm{dL}$ to $129.95 \pm 40.61 \mathrm{mg} / \mathrm{dL}$ after 16 weeks paroxetine treatment reported by Beyazyüz et al. [13] was also calculated to be 61 $\mathrm{ng} / \mathrm{mL}$ using a formula (d) as below:

Paroxetine mean serum concentration in the 20 patients [13] $=75(129.95-92.25) / 46.49$

SSRIs reportedly inhibit insulin signaling and beta cell function in a dose-dependent manner [16]. SSRIs paroxetine and sertraline are potential inducers of insulin resistance by activating a number of IRS kinases, JNK included, leading to increased Ser/Thr phosphorylation of insulin receptor substrate-1 (IRS-1) with a concomitant reduction in its ability to undergo insulin-induced Tyr phosphorylation of IRS-1 with half-maximal effects at $\sim 10 \mu \mathrm{M}$ [15]. While, SSRIs are highly lipophilic and may accumulate in tissues. Levkovitz et al. referred an estimated ratio of $20: 1$ for the relative 
partition of fluoxetine between specific tissue (e.g. liver) and blood, high accumulation of fluoxetine into tissue spaces with an apparent tissue to plasma ratio of $12-43: 1$, and a brain-to-plasma ratio of $10: 1$ of fluoxetine [15]. Lewis et al. determined the distribution of paroxetine in postmortem tissues and fluids, and the distribution of paroxetine, expressed as mean specimen/blood ratio, was $5.77 \pm 1.37$ liver $(\mathrm{N}=8)$ and $4.27 \pm 2.64$ brain $(\mathrm{N}=7)$ [41]. Therefore, it is estimated that the concentrations of paroxetine in Mr. A's serum calculated in the range of $161-387 \mathrm{ng} / \mathrm{mL}(0.5-1.2 \mu \mathrm{M})$ were accumulated several times more in tissues, and reached into the effective concentrations to induce insulin resistance on June $4^{\text {th }}, 2010$.

The TG-Cal/HDL-C ratios were calculated for Mr. A to be in the range of $3.8-5.9(200 / 53-311 / 53)$ as summarized in Table 2, and shown in Fig. 2c. For comparison, in the levels reported by Beyazyüz et al. [13], the TG/HDL-C ratios were calculated and the increase of the ratio from $1.7(92.25 / 54.01=1.7)$ to $2.4(129.95 / 53.71=2.4)$ after 16 weeks of paroxetine treatment for the 20 patients are also shown in Fig. 2c. The TG-Cal/HDL-C ratios in the range of $3.8-5.9$ calculated for Mr. A (Table 2) were much higher than the ratios 1.7 and 2.4 for the 20 patients [13] (Fig. 2c). Ray et al., reported that the TG/HDL-C ratio was significantly correlated with HOMA-IR [27]. According to the graph reported by Ray et al. [27], the range of TG-Cal/HDL-C ratios $3.8-5.9$ corresponded to HOMA-IR $\geq 4$. The TG/HDL-C concentration $(\mathrm{mg} / \mathrm{dL})$ ratio $\geq 3.5$ and HOMA-IR $\geq 2.5$ are thought to be the indicators in identifying individuals who are insulin resistant $[19,23]$.

Taken together, TG-Cal values in the range of $200-311 \mathrm{mg} / \mathrm{dL}$, the serum concentrations of paroxetine in the range of $161-387 \mathrm{ng} / \mathrm{mL}(0.5-1.2 \mu \mathrm{M})$, and the TG-Cal/HDL-C ratios in the range of $3.8-5.9$ as calculated above and summarized in Table 2 suggest the possible onsets of hypertriglyceridemia, higher body concentration of paroxetine, and insulin resistance in $\mathrm{Mr}$. A on the $14^{\text {th }}$ day after the start of paroxetine treatment.

\section{5 Relation between insulin resistance and blood glucose levels}

Insulin resistance does not always involve the high concentration of blood glucose according to the results by Fujii et al. [18], Samant et al. [26], and Yin et al. [42]. The results reported by Fujii et al. [18] and Samant et al. [26] suggested that patients with possible insulin resistance defined by HOMA-IR $\geq 2.5$ [19] were not in the condition of high blood glucose, but the patients with diabetes were in the condition of high blood glucose [18]. The blood glucose levels $109.4 \pm$ $1.5 \mathrm{mg} / \mathrm{dL}$ [18] and $113 \pm 1.19 \mathrm{mg} / \mathrm{dL}$ [26] were reported for the subjects $(\mathrm{N}=71)$ classified as impaired glucose tolerant (IGT) with HOMA-IR $2.7 \pm 0.3[18]$ and the subjects $(\mathrm{N}=60)$ classified as metabolic syndrome group with TG/HDL-C ratio $4.554 \pm 0.152$ and HOMA-IR $6.14 \pm 0.09$ [26]. Mr. A's blood glucose level $111 \mathrm{mg} / \mathrm{dL}$ (Table 1) was comparable to both the levels $109.4 \pm 1.5 \mathrm{mg} / \mathrm{dL}$ [18] and $113 \pm 1.19 \mathrm{mg} / \mathrm{dL}$ [26], but significantly lower than the levels $141.6 \pm 4.8$ $\mathrm{mg} / \mathrm{dL}$ reported for diabetes $(\mathrm{N}=7)$ by Fujii et al. [18] and $133.2 \mathrm{mg} / \mathrm{dL}(7.40 \mathrm{mmol} / \mathrm{L})$ at the time for diagnosis for incident diabetes $(\mathrm{N}=164)$ reported by Tabák et al. [20]. Yin et al. summarized the characteristics of study population according to the number of metabolic abnormalities in the table where the values of fasting blood glucose (FBG) 4.91, $5.13,5.18$, and $6.41 \mathrm{mmol} / \mathrm{L}(88.3,92.3,93.2$, and $115.3 \mathrm{mg} / \mathrm{dL})$ were presented for the values of HOMA-IR 1.42, 2.33, 3.03, and 4.96, respectively [42] [Blood Sugar Converter, https://www.diabetes.co.uk/blood-sugar-converter.html]. These values indicated that patients with HOMA-IR 3.03 or 4.96 did not have high levels but normal or moderately high level of glucose 93.2, or $115.3 \mathrm{mg} / \mathrm{dL}$ [42]. Because Mr. A's blood glucose level $111 \mathrm{mg} / \mathrm{dL}$ was measured at 15:56, after about four hours of his taking alcohol around noon on June $4^{\text {th }}, 2010$ (Table 1), it was not certain whether glucose decreased to the fasting level or not. But the level $111 \mathrm{mg} / \mathrm{dL}$ was comparable to the fasting glucose level $115.3 \mathrm{mg} / \mathrm{dL}$ reported for the patients with HOMA-IR 4.96 by Yin et al. [42]. Even if the fasting glucose level in Mr. A was lower than the measured value $111 \mathrm{mg} / \mathrm{dL}$, it was possibly comparable to the value $93.2 \mathrm{mg} / \mathrm{dL}$ reported for the patients with HOMA-IR 3.03 by Yin et al. [42]. Therefore, the possible onset of insulin resistance in Mr. A cannot be denied by the glucose level $111 \mathrm{mg} / \mathrm{dL}$ (Table 1).

Tabák et al. characterized trajectories of fasting and post-load glucose, insulin sensitivity, and insulin secretion in individuals who developed type 2 diabetes [20]. They reported that a linear increase in fasting glucose (from 5.47 $\mathrm{mmol} / \mathrm{L}$ to $5.79 \mathrm{mmol} / \mathrm{L}$ ) (from $98.5 \mathrm{mg} / \mathrm{dL}$ to $104.2 \mathrm{mg} / \mathrm{dL}$ ) from 13 years to 3 years before diagnosis was followed by a steep quadratic increase (from $5.79 \mathrm{mmol} / \mathrm{L}$ to $7.40 \mathrm{mmol} / \mathrm{L}$ ) (from $104.2 \mathrm{mg} / \mathrm{dL}$ to $133.2 \mathrm{mg} / \mathrm{dL}$ ) starting 3 years before diagnosis of diabetes. For the incident diabetes cases, a linear trend of fasting plasma glucose from 13 years to 3 years before diagnosis but with a steeper slope than nondiabetics was reported with slope difference $0.028 \mathrm{mmol} / \mathrm{L}(0.5$ $\mathrm{mg} / \mathrm{dL}$ ) per year.[20]. While, according to the results reported by Beyazyüz et al., fasting plasma glucose levels increased from 92.35 to $101.65 \mathrm{mg} / \mathrm{dL}$ before and after the 16 weeks paroxetine treatment for the 20 patients [13] as shown in Fig. 2b. The slope difference for the increase of fasting glucose was calculated to be $(101.65-92.35) \times 52 / 16=$ $30.2 \mathrm{mg} / \mathrm{dL}(1.7 \mathrm{mmol} / \mathrm{L})$ per year, which was about 60 times faster than the value $0.5 \mathrm{mg} / \mathrm{dL}(0 \cdot 028 \mathrm{mmol} / \mathrm{L}) \mathrm{per}$ year reported for the incident diabetes cases by Tabák et al. [20]. The calculated TG/HDL-C ratio in the 20 patients also increased from $1.71(92.25 / 54.01)$ to $2.42(129.95 / 53.71)$ by the 16 weeks paroxetine treatment [13] as shown in Fig. 2c suggesting the acceleration of trajectory to insulin resistance by paroxetine. The acceleration was thought to be more rapid in Mr. A than in the 20 patients, because the serum concentrations of paroxetine in the range of $161-387 \mathrm{ng} / \mathrm{mL}$ 
(Table 2) calculated for Mr. A were much higher than the mean paroxetine serum concentration $61 \mathrm{ng} / \mathrm{mL}$ calculated for the 20 patients [13] as above.

\section{6 Timing of the TG increase and onset of possible insulin resistance in the patient}

Lewis reported that the typical dyslipidemia of insulin resistant states was characterized by hypertriglyceridemia, low HDL, and small dense LDL particles [29]. Lewis and his colleagues showed that the hypertriglyceridemia in an insulin resistant state led to modification of HDL composition, and lowered the HDL concentration in a delayed fashion [29]. The delay and mechanism of HDL-C lowering after the onset of hypertriglyceridemia of the insulin resistant state have been studied by Lewis et al., Lamarche et al., Greene et al., Vega et al., Gingsberg et al., and Rader et al. [29 - 34]. Yin et al. reported the values of TG and HDL-C obtained in Chinese children and adolescents aged $6-18$ years $(\mathrm{N}=3203)$ [42]. The levels of TG, $0.78 \pm 0.21,1.03 \pm 0.51,1.19 \pm 0.56$, and $1.67 \pm 0.80 \mathrm{mmol} / \mathrm{L}(69 \pm 19,91 \pm 45,105 \pm 50$, and $148 \pm 71 \mathrm{mg} / \mathrm{dL})$ were respectively presented for the levels of HDL-C, $1.55 \pm 0.29,1.41 \pm 0.30,1.28 \pm 0.26$, and $1.1 \pm$ $0.22 \mathrm{mmol} / \mathrm{L}(60 \pm 11,55 \pm 12,49 \pm 10$, and $43 \pm 9 \mathrm{mg} / \mathrm{dL})$ with increasing values of HOMA-IR $1.42 \pm 0.96,2.33 \pm$ $1.77,3.03 \pm 1.81$, and $4.96 \pm 5.48$ [42] [Cholesterol conversion http://www.onlineconversion.com/cholesterol.htm]. Using these values, two equations were calculated by linear approximation using Excel as below to indicate that the HDL-C level decreased by $4.7918 \mathrm{mg} / \mathrm{dL}$ on average with the increase of TG level by $21.867 \mathrm{mg} / \mathrm{dL}$ in the results by Yin et al. [42]. The ratio of HDL-C decrease divided by TG increase was $0.22(4.7918 / 21.867=0.22)$.

$$
\begin{array}{ll}
y=21.867 x+38.82 & \left(R^{2}=0.9993\right) \\
z=-4.7918 x+65.814 & \left(R^{2}=0.9553\right)
\end{array}
$$

(Terms x, y, and z represent HOMA-IR, TG, and HDL-C mean levels (mg/dL) from Yin et al. [42], respectively.)

Kathiresan et al. also reported the similar tendency between the TG level increase and HDL-C level decrease obtained in men $(\mathrm{N}=1404$, age $50 \pm 10$ y) [28]. In their report, the mean TG levels $71 \pm 3,96 \pm 3,133 \pm 3,178 \pm 4,214 \pm 5$, and $231 \pm 10 \mathrm{mg} / \mathrm{dL}$ were respectively presented for the levels of the mean HDL-C levels $52 \pm 1,48 \pm 1,43 \pm 1,37 \pm 1,33 \pm$ 1 , and $32 \pm 2 \mathrm{mg} / \mathrm{dL}$ with increasing numbers of MetSyn components $(0,1,2,3,4$, and 5) [28]. Using these values, two equations were also calculated by linear approximation using Excel as below to indicate that the HDL-C level decreased by $4.3143 \mathrm{mg} / \mathrm{dL}$ on average with the increase of TG level by $34.257 \mathrm{mg} / \mathrm{dL}$ in the results by Kathiresan et al. [28]. The ratio of HDL-C decrease divided by TG increase was $0.13(4.3143 / 34.257=0.13)$.

$$
\begin{array}{ll}
y=34.257 x+68.19 & \left(R^{2}=0.9874\right) \\
z=-4.3143 x+51.619 & \left(R^{2}=0.9728\right)
\end{array}
$$

(Terms x, y, and z represent MetSyn numbers, TG, and HDL-C mean values from Kathiresan et al. [28], respectively)

Fjukstad et al. studied the metabolic abnormalities related to treatment with SSRIs in the patients (all patients $\mathrm{N}=$ 1301, patients using SSRIs $\mathrm{N}=280$, aged $18-65$ years, mean 31.7$)$, and reported that an SSRI serum concentration in the middle of the reference interval was associated with an increase of the TG level by $46.49 \mathrm{mg} / \mathrm{dL}$ (CI $26.53-66.46$ $\mathrm{mg} / \mathrm{dL}, P<0.001)$, while it was associated with a decrease of the HDL-C level by $3.30 \mathrm{mg} / \mathrm{dL}(\mathrm{CI}-6.89-0.29 \mathrm{mg} / \mathrm{dL}, P$ $=0.071)$ [14]. The ratio of HDL-C decrease divided by TG increase was $0.07(3.30 / 46.49=0.07)$.

Beyazyüz2013 et al. reported that the parameters of TG increased from $92.25 \pm 19.41 \mathrm{mg} / \mathrm{dL}$ to $129.95 \pm 40.61$ $\mathrm{mg} / \mathrm{dL}$, while HDL-C decreased from $54.01 \pm 4.85 \mathrm{mg} / \mathrm{dL}$ to $53.71 \pm 6.46 \mathrm{mg} / \mathrm{dL}$ in the 20 patients aged $20-41$ years without any metabolic comorbidity after 16 weeks of paroxetine treatment [13]. The ratio of HDL-C decrease divided by TG increase was $0.008((54.01-53.71) /(129.95-92.25)=0.008)$. Comparison among the four ratios $0.22,0.13,0.07$ and 0.008 suggested that the degree of HDL-C lowering was probably associated with age difference among the populations of patients, exposure period to the hypertriglyceridemia state and its degree, and 16 weeks of paroxetine treatment [13] were not long enough for the sufficient lowering of HDL-C levels after the increase of TG levels caused by the mean paroxetine concentration $61 \mathrm{ng} / \mathrm{mL}$ calculated and estimated as above.

The calculated TG values (TG-Cal) in the range of $200-311 \mathrm{mg} / \mathrm{dL}$ for Mr. A (Table 2) were comparable to the TG levels $214 \pm 5$ and $231 \pm 10 \mathrm{mg} / \mathrm{dL}$ in the groups with 4 and 5 components of MetSyn features reported by Kathiresan $e t$ al. [28]. While, the measured HDL-C value $53 \mathrm{mg} / \mathrm{dL}$ in Mr. A (Table 1) was comparable to the HDL-C level $52 \pm 1$ $\mathrm{mg} / \mathrm{dL}$ in the group with 0 component of MetSyn features reported by Kathiresan et al. [28]. These comparisons suggested that the deadly increase of TG concentration had already occurred, but lowering of the HDL-C concentration had not yet occurred in Mr. A on June $4^{\text {th }}, 2010$ after 14 days treatment of paroxetine, and therefore, hypertriglyceridemia and possible insulin resistance were steeply developed in the patient, and a possible cause was the exposure to higher serum concentration of paroxetine in the range of $161-387 \mathrm{ng} / \mathrm{mL}$ as calculated and estimated above (Table 2).

\section{7 The abnormal dosing interval $10 \mathrm{mg}$ twice daily generated higher trough concentration of paroxetine than the guideline-recommended dosing interval $20 \mathrm{mg}$ once daily would have done}


FDA informed that Paxil should be administered as a single daily dose and the recommended initial dose is $20 \mathrm{mg} / \mathrm{day}$ [1]. Heydorn et al. reported that the plasma half-life of paroxetine at steady state was about 21 hours, and due to its long half-life, paroxetine should be administered once daily [43]. Toutain and Bousquet-Mélou reported when the same total daily dose was administered but with two dosing intervals (12 and $24 \mathrm{~h}$ ), the relevant difference was the degree of plasma concentration excursion (i.e. the extent of the difference between peak and trough plasma concentrations) [44]. That is, the trough concentrations generated by the dosing interval $12 \mathrm{~h}$ (BID) are definitely higher than those generated by the dosing interval $24 \mathrm{~h}$ (SID), and BID with higher trough concentrations increases total exposure of targets to the drug toxicity than SID [44]. In paroxetine treatment, the target is generally thought to be the serotonin transporter protein, but one of the hepatic enzymes CYP2D6 that metabolizes paroxetine is also another target, because paroxetine is a mechanism-based inhibitor of CYP2D6 [45, 46]. The mechanism-based inhibition (MBI) is most likely caused by an irreversible binding of a paroxetine-reactive metabolite that does not leave the active site, to the heme complex in the P450 enzyme [45, 46, 47 and 48]. Lam et al. reported that inhibition of CYP2D6 correlated significantly with trough plasma concentrations of paroxetine [49]. Livezey et al. reported the remaining activity of CYP2D6 (\%) as a function of the concentration ratio of paroxetine to CYP2D6 ([paroxetine]/[CYP2D6]), and the partition ratio value for paroxetine was 70 [50]. Partition ratio is a measure of the number of molecules metabolized per molecule of CYP2D6 inactivated [50], suggesting that inhibition and inactivation of CYP2D6 are enhanced by increasing the concentration of paroxetine.

Psychiatrist B prescribed paroxetine $10 \mathrm{mg}$ twice daily for total 35 days to Mr. A. According to the explanation and results reported previously [44, 49], the plasma trough concentration of paroxetine is absolutely higher in the dosing interval $10 \mathrm{mg}$ twice daily than in $20 \mathrm{mg}$ once daily. Therefore, it is certain that the main metabolizer of paroxetine CYP2D6 was more intensely inhibited by the abnormal dosing interval $10 \mathrm{mg}$ twice daily in the patient than by the normal dosing interval $20 \mathrm{mg}$ once daily. It is thought that abnormally enhanced inactivation of CYP2D6 resulted in the significant accumulation of paroxetine in the patient.

\section{8 Lower levels of CYP2D6*1 and higher concentrations of paroxetine in young adults and CYP2D6*1/*10 carriers}

Mann et al. reported that CYP2D6 increased from fetal to 80 years of age $(\mathrm{N}=76)$, exhibiting 3 distinct phases of change. From birth to infancy, CYP2D6 expression significantly increased with age (birth - 0.9 years), while no apparent further increase was observed until adulthood (1 - 19 years) [51]. A second phase of increase in CYP2D6 occurred from 20 to 80 years of age [51]. Referring to the graph reported by Mann et al. [51], the CYP2D6 protein levels in 20 year-old adults are less than half compared to those in $40-80$ year-old adults, suggesting that the CYP2D6 protein level and enzymatic activity to metabolize paroxetine are lower than half in children, adolescents, and young adults (ages 20 -24) including Mr. A aged 20-year-old compared to those in middle-aged adults.

Ueda et al. investigated the effect of the CYP2D6 genotypes on the plasma concentration of paroxetine in 55 Japanese psychiatric patients [52]. They were administered 10 to $40 \mathrm{mg} /$ day of paroxetine and maintained at the same daily dose for at least two weeks to obtain the steady-state concentrations. The allele frequencies of the $C Y P 2 D 6 * 5, C Y P 2 D 6 * 10$ and $C Y P 2 D 6 * 41$ as decreased functional genes were $1.8 \%, 41.8 \%$ and $1.8 \%$, respectively. Significantly higher paroxetine concentrations were observed in the subjects having one $C Y P 2 D 6 * 1$ allele $(243.6 \pm 25.2 \mathrm{ng} / \mathrm{mL}) \mathrm{compared}$ with the subjects having two $C Y P 2 D 6^{*} 1$ alleles $(150.9 \pm 20.6 \mathrm{ng} / \mathrm{mL})$ or no $C Y P 2 D 6^{*} 1$ allele $(76.7 \pm 6.1 \mathrm{ng} / \mathrm{mL})$ in the group with $30 \mathrm{mg} /$ day of paroxetine [52]. The similar trends of findings were observed in the subjects treated with 20 and $40 \mathrm{mg} /$ day of paroxetine [52]. The results suggested that the patient with one functional and one less-functional alleles such as $C Y P 2 D 6^{*} 1 / * 10$ had a tendency to exhibit the high plasma concentration of paroxetine when relatively high daily dose was administered.

Ramamoorthy et al. reported that using dextromethorphan as a substrate, the Ki values for paroxetine to inhibit CYP2D6*1 and CYP2D6*10 were $0.2 \mu \mathrm{M}$ and $3.3 \mu \mathrm{M}$, respectively [53], suggesting CYP2D6*1 was inhibited by paroxetine more than 10 times potently than CYP2D6*10. While, Feng et al. reported population pharmacokinetic (PK) model to describe paroxetine data in the elderly depressed population $(\mathrm{N}=171)$ [54]. The maximal velocity $(\mathrm{Vm})$ estimates in each of the CYP2D6 phenotypic groups were: $125 \mu \mathrm{g} \mathrm{h}^{-1}$ in poor metabolizer $(\mathrm{N}=1), 182 \mu \mathrm{g} \mathrm{h}{ }^{-1}$ in intermediate metabolizers $(\mathrm{N}=28), 454 \mu \mathrm{g} \mathrm{h}^{-1}$ in extensive metabolizers $(\mathrm{N}=36)$, and $3670 \mu \mathrm{g} \mathrm{h} \mathrm{h}^{-1}$ in ultra-rapid metabolizers $(\mathrm{N}=5)$ [54]. CYP2D6*1/*10 carriers were classified into the group of intermediate metabolizers, and $C Y P 2 D 6^{*} 1 / * 1$ carriers were classified into the group of extensive metabolizers [54]. These results suggest that CYP2D6*1 is more active in paroxetine metabolism, but more potently inhibited and eliminated by paroxetine than CYP2D6*10. And the concentration-dependent inhibition effect by paroxetine in $C Y P 2 D 6 * 1 / * 10$ carriers is stronger than that in $C Y P 2 D 6 * 1 / * 1$ carriers, because the concentration of the CYP2D6*1 enzyme molecule is $50 \%$ lower in the former than in the latter. Sakuyama et al. reported that allele frequencies of $C Y P 2 D 6 * 1$ and $C Y P 2 D 6 * 10$ in Japanese were 39.8 - 43.0\% and 34.6 - 40.8\%, respectively [55]. CYP2D6*1 and $C Y P 2 D 6 * 10$ are the two most frequent alleles in Japanese. And Mr. A had a possibility to carry $C Y P 2 D 6^{*} 1 / * 10$ or $C Y P 2 D 6 * 1 / * 1$ with a probability of $50 \%$ each, because his parents are the carriers of $C Y P 2 D 6^{*} 1 / * 10$ and $C Y P 2 D 6^{*} 1 / * 1$, respectively. The young age of Mr. A was associated with lower levels of expression and concentration of CYP2D6 [51], and the dosing interval $10 \mathrm{mg}$ twice daily produced 
the higher trough concentration of paroxetine than that of $20 \mathrm{mg}$ once daily [44] and enhanced the inhibition of CYP2D6*1 [49]. In addition to these two factors, if Mr. A was a carrier of $C Y P 2 D 6 * 1 / * 10$, it should have produced the half level of CYP2D6*1 and much more enhanced inhibition of CYP2D6*1 as reported by Ueda et al. [52] to lead to the highest possible concentration of paroxetine.

\section{9 Associations between higher paroxetine concentrations and suicides}

Coupland et al. examined antidepressant use and risk of suicide in the cohort study $(\mathrm{N}=238,963)$, and found that both the unadjusted and adjusted hazard ratios for suicide tended to increase significantly with dose for SSRIs [9]. The unadjusted hazard ratios for suicide were 0.20 (0.03 to 1.41), 1.00, and 1.74 (1.07 to 2.81) for SSRIs dose categories (defined daily doses) $\leq 0.5,>0.5$ and $\leq 1.0$, and $>1.0$, respectively. They also calculated hazard ratios to adjust for various potential confounding variables including severity of depression. The adjusted hazard ratios for suicide were 0.22 (0.03 to 1.60$), 1.00$, and 1.55 (0.95 to 2.53$)$ for the same dose categories, respectively [9], suggesting dose-related increase of suicides. The mean maximal paroxetine concentrations (Cmax) referred in the Paxil prescription information in the Japanized version [1] were non-linearly increased by $1.93 \pm 1.38,6.48 \pm 4.10$, and $26.89 \pm 11.00 \mathrm{ng} / \mathrm{mL}$ after a single dose administration of paroxetine 10,20 , and $40 \mathrm{mg}$, respectively $(\mathrm{N}=19)$, suggesting pharmacokinetic nonlinear association between doses and concentrations. Similar results were reported by Heydorn et al. that the Cmax values were $13.7(1.4$ - 39.2) and $61.7(8.6$ - 105) ng/mL following a single dose and 30 daily doses of paroxetine 30 mg, respectively [43].

In SSRIs drugs, the hazard ratio for suicide was highest for paroxetine among the five SSRIs (citalopram 1.00, escitalopram 0.93 ( 0.32 to 2.64 ), fluoxetine 0.96 (0.56 to 1.65$)$, paroxetine 1.95 (0.96 to 3.95), and sertraline 1.15 ( 0.51 to 2.59)) [9]. Suicide rates tended to be highest in the first 28 days after starting treatment and remained increased in the first 28 days after stopping treatment [9]. The results indicated that patients taking antidepressant drugs should be carefully monitored, especially during early treatment with antidepressants and when stopping treatment [9]. In Mr. A's case, higher paroxetine concentrations in the range of $161-387 \mathrm{ng} / \mathrm{mL}$ were estimated on the $14^{\text {th }}$ day, and the suicide was carried out on the $41^{\text {st }}$ day after three days of abrupt discontinuation of paroxetine. Both the results probably suggest associations between higher paroxetine concentrations and suicides.

\section{10 Litigations and decisions with confidentiality of doctors prioritized over advices to the family}

In 2013, based on the Code of Civil Procedure, the family who learned of the higher risk of suicide and paroxetine in the young population by reading the Paxil package warning messages after the death of Mr. A, filed a lawsuit against Psychiatrist B who prescribed paroxetine to Mr. A. However, the plaintiff was defeated both in the district court (Presiding Judge Keiji Noda) in 2016 [the 25 year of the Heisei era (Wa) issue No.765 a damage suit] [56], and in the high court (Presiding Judge Mitsuhiro Ikeda) in 2017 [the 28 year of the Heisei era (Ne) issue No.1973 a damage suit] [57].

One of the issues in the lawsuits was whether Psychiatrist B fulfilled the duties (I IV) to properly prescribe paroxetine. Psychiatrist B did not make the diagnosis based on the DSM-IV criteria (I), did not prescribe paroxetine once daily according to the medication guide [1] (II), did not advise Mr. A himself or his family of the need for close observation against suicide risk possibly caused by taking or abrupt stopping paroxetine according to the warning message in the medication guide [1] (III), or did not taper the paroxetine dose down to stop it by the third consultation day (June $\left.14^{\text {th }}, 2010\right)$ at the latest, in spite of hearing about abnormal behaviors of Mr. A by telephone from the doctor of Hospital C on June $4^{\text {th }}, 2010$ (IV). A psychiatrist outside Japan Dr. L wrote in the opinion brief as follows: "I have seen no evidence that, at the first consultation, Mr. A was examined for depression or that he was suffering from depression. He presented as worried and self-conscious, a state usually diagnosed as 'anxiety'." But, in the ruling, the judges never admitted the Psychiatrist B's negligence, because it was difficult for them to decide that Mr. A's suicide could be avoided if paroxetine was not prescribed to Mr. A. The judges wrote that it was impossible to correctly evaluate the measured values, because the levels in the blood examination measured at 15:56 on June $4^{\text {th }}, 2010$ were not obtained in the fasting condition, and it was impossible to presume instantly that the activation syndrome was developed with paroxetine when Mr. A carried out the suicide, even if the concentration of paroxetine was high in Mr. A at that time.

Another issue in the lawsuit was whether the suicide was foreseeable in the period of paroxetine prescription. In the ruling, the judges decided that it was not possible for Psychiatrist B to foresee the occurrence of suicide in the prescription period of paroxetine to Mr. A based on the following sentences: "The psychiatrist was not able to foresee the suicide because he did not observe clear symptoms of suicidality on the third consultation (June 14 $\left.{ }^{\text {th }}, 2010\right)$. The psychiatrist was not in a situation where he was able to foresee the suicide or to advise to his family, because the suicide was carried out in the initial stage of treatment to construct a good relation between a doctor and a patient, and advices to his family were thought to incur a destruction of their good relationship and to make a breach in confidentiality of doctors". The judges ruled that it was not possible for Psychiatrist B to advise Mr. A's family of the need for close observation against "confidentiality of doctors". They prioritized "confidentiality of doctors" over "advices to the family" 
of clinical worsening and suicide risk during paroxetine exposure [56, 57].

\subsection{Advices of suicide risk and paroxetine should be given to the patient and family at the start of treatment}

However, the suicide would have been a foreseeable and preventable event, if the defendant psychiatrist fulfilled the duties (I IV). Psychiatrist B never asked Mr. A about suicidal thought to foresee his suicide. The court rulings never based on the black-boxed warning [1], which is indispensable to save the patient's life. Williams and Ellison reported about the duty to warn and protect by citing the sentences "When counselors, through their confidential relation with clients, learn that a vulnerable person is at risk of harm, they have a duty to act to prevent the harm. This is a higher duty than the duty to maintain confidentiality." [58]. Patients will be exposed to the risk from paroxetine and become vulnerable to the risk of suicide after the start of treatment [1]. Psychiatrist B should have learnt the suicide risk from paroxetine exposure by reading the black boxed warning [1]. If Psychiatrist B advised both Mr. A himself and his family of the need for close observation and the reason, on the first consultation day, Mr. A could have noticed that his developing suicidality was possibly caused by paroxetine, and could have talked it over with his doctor or family, and the suicide could have been prevented by them who could take the things together. Advices to the patient and family should be given at the start of paroxetine treatment, because it is unknown when suicidality will develop after the start of paroxetine treatment, or how they should notice the developing suicidality in the patient treated with paroxetine. It would be better that the timing to give advices is additionally written in the black-boxed warning of the Paxil package insert Japanized version.

\subsection{Comparison between the decisions and facts}

The judges wrote the sentences in the decisions. Some sentences are translated as follows; Mr. A's sending emails with advanced notice of suicide to Miss E were not caused by Paxil but caused by the disappointment in love with her. Mr. A's TG level was possibly high before taking Paxil, because of no evidence that the TG level was low in Mr. A before the Paxil treatment. Mr. A did not develop insulin resistance, because his blood glucose level $111 \mathrm{mg} / \mathrm{dL}$ was not high enough to support the onset of insulin resistance. Therefore, the high blood concentration of Paxil in Mr. A is considered to be unacceptable as evidence. The expert psychiatrist $\mathrm{F}$ expressed the opinion that the patient was directed to take Paxil twice daily by dividing $20 \mathrm{mg}$ into $10 \mathrm{mg}$, which was different from the dosage and administration recommended in the package insert of Paxil, but, it is not uncommon that such dosage and administration are made at "doctor's professional freedom for prescription" in the clinical practice of psychiatry. Therefore, there is no evidence that the dosing interval $10 \mathrm{mg}$ twice daily made high blood concentration of Paxil in Mr. A. The psychiatry professor G expressed the opinion that suicides caused by Paxil are not deliberate but impulsive in the majority of cases. Therefore, Mr. A's suicide caused by generating hydrogen sulfide in a car after leaving a suicide note is not likely the case. It is difficult to decide on each case individually based on the statistical results such as the suicide rates reported in scientific literatures. As a factor except Paxil, we consider that the level of Mr. A's pre-existing depression was possibly more serious to carry out suicide than the defendant psychiatrist expected.

The emails with advanced notice of suicide were not sent at the time of disappointment in love in late April 2010 before the paroxetine treatment, but were sent on May $28^{\text {th }}$, June $7^{\text {th }}$, and $8^{\text {th }}$ (the $7^{\text {th }}, 17^{\text {th }}$, and $18^{\text {th }}$ days) after the start of paroxetine treatment as shown in Fig. 1. The abnormal behaviors on June $4^{\text {th }}, 2010$ (the $14^{\text {th }}$ day) were not observed before paroxetine treatment. However, the judges concluded that because such emails and behaviors could be sent and caused without activation by Paxil, these are not the evidential events to support the development of activation syndrome by Paxil. The blood glucose level $111 \mathrm{mg} / \mathrm{dL}$ cannot be an exclusive factor of insulin resistance independently. The judges seemed to confuse insulin resistance with diabetes, which is generally known to involve high FG levels such as $141.6 \pm 4.8 \mathrm{mg} / \mathrm{dL}$ [18] and $133.2 \mathrm{mg} / \mathrm{dL}(7.40 \mathrm{mmol} / \mathrm{L})$ [20]. If psychiatrists easily change dosing intervals of medications without knowledge of pharmacokinetics, their professional freedoms will lead to occurrences of drug toxicity as reported by Toutain et al. [44]. Kraus et al. reported that several long detailed suicide-notes were written by the subjects who developed definitive suicidal behavior in the MDD and non-MDD cases following initiation of paroxetine therapy [59]. Donovan $e t$ al. reported that significantly more deliberate self-harm events occurred following prescriptions of SSRI such as paroxetine than those of TCA [60]. Khan et al. reported that method of suicide did not appear to differ among depressed patients assigned to SSRI antidepressants and those assigned to other antidepressants or to placebo [61]. Against the opinion of Professor G, method of suicide does not appear to be any more impulsive for SSRI antidepressants than for other antidepressants [61]. A question remained why the suicide rate 799 [10] which was approx. 10 times higher than those for depression and anxiety, did not make the judges to decide that the suicide could be avoided if paroxetine was not prescribed. The judges possibly avoided the involvement of paroxetine in the suicide by speculating that Mr. A's pre-existing depression was serious enough to carry out suicide. They never examined the temporal changes in behavior between before and after the start of paroxetine exposure, but remained to separately deny each evidence. Whether true or not, it is an undeniable fact that the suicide was carried out during and after exposure to paroxetine. 


\section{CONCLUSIONS}

Suicidal preoccupation and suicide completion occurred in the patient in the first 41 days of the first three months following initiation of paroxetine exposure. In this period, paroxetine exposure increased the suicide rate by about ten times. The higher TG-Cal values in the range of $200-311 \mathrm{mg} / \mathrm{dL}$, the normal HDL-C concentration $53 \mathrm{mg} / \mathrm{dL}$, the TG$\mathrm{Cal} / \mathrm{HDL}-\mathrm{C}$ ratios in the range of $3.8-5.9$, and the paroxetine serum concentrations in the range of $161-387 \mathrm{ng} / \mathrm{mL}$ calculated as above probably suggest the development of acute insulin resistance and higher body concentration of paroxetine. Based on these results, I consider that paroxetine exposure was probably associated with the patient's suicide. Conversely, higher TG and normal HDL-C concentrations and the TG/HDL-C ratios $\geq 3.5$ are potentially useful to estimate and predict higher body concentrations of paroxetine and harmful outcomes. When follow-up measurements of TG and HDL-C concentrations and TG/HDL-C ratios are performed in the early months of medication, and mechanism understandings of these lipid level changes grow in practical psychiatrists, most suicides during paroxetine exposure might be preventable. The usability needs to be confirmed in further studies.

\section{LIMITATIONS}

The levels were mostly calculated and estimated, because there were no measured values of glucose and lipid levels before the paroxetine treatment, and the measured values of glucose, TG, TC, HDL-C and LDL-C were not obtained in the fasting condition. It was not possible to compare actual measured values before and after paroxetine exposure. In order to estimate and predict higher body concentrations of paroxetine and harmful outcomes by the lipid level changes, follow-up measurements of TG and HDL-C concentrations and TG/HDL-C ratios should be carried out before and after the start of paroxetine exposure. 


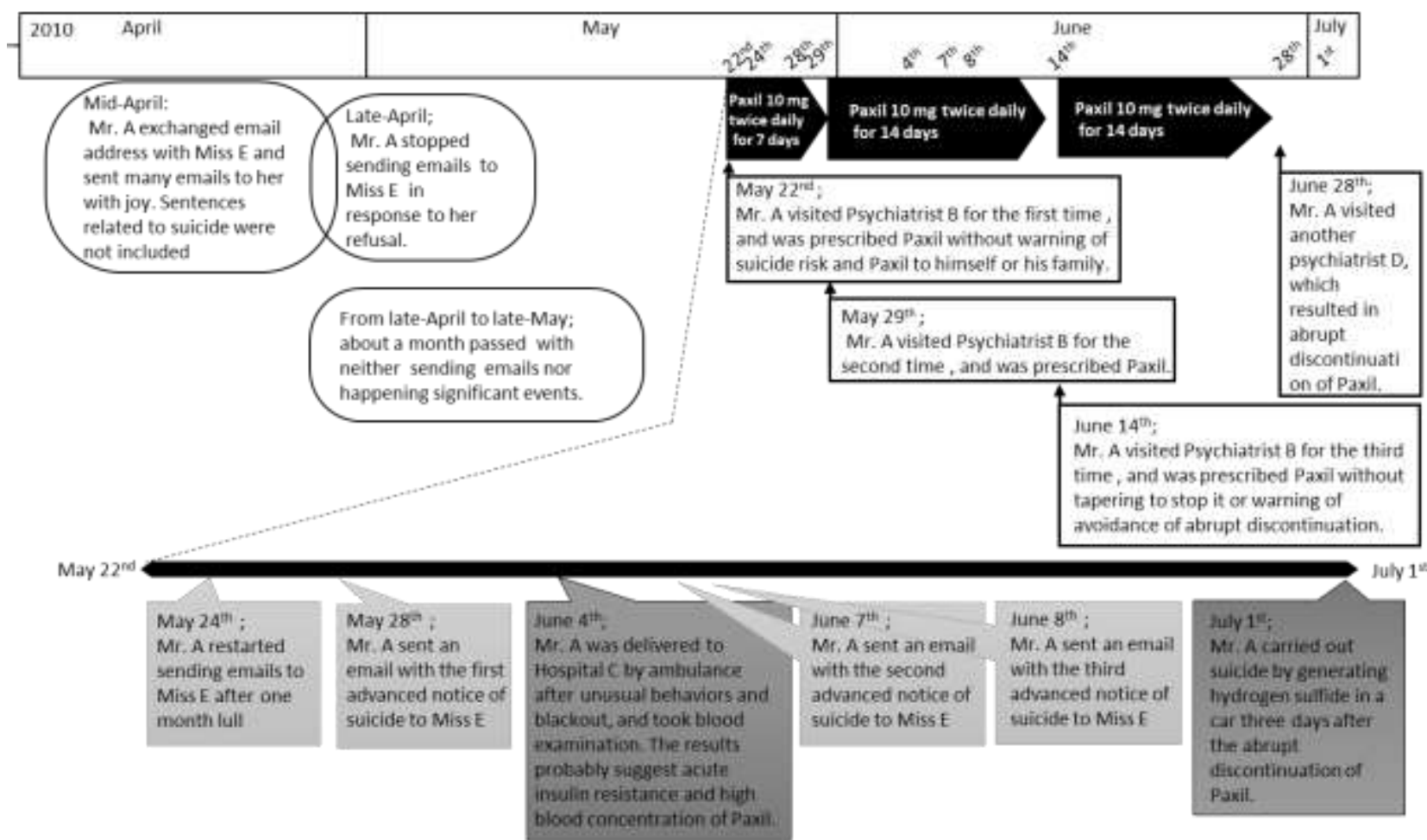

Figure 1: A timeline chart of psychiatric consultations, Paxil prescriptions, emails sent without or with advanced notice of suicide, an ambulance transport after unusual behaviors, and suicide completion 
(a)

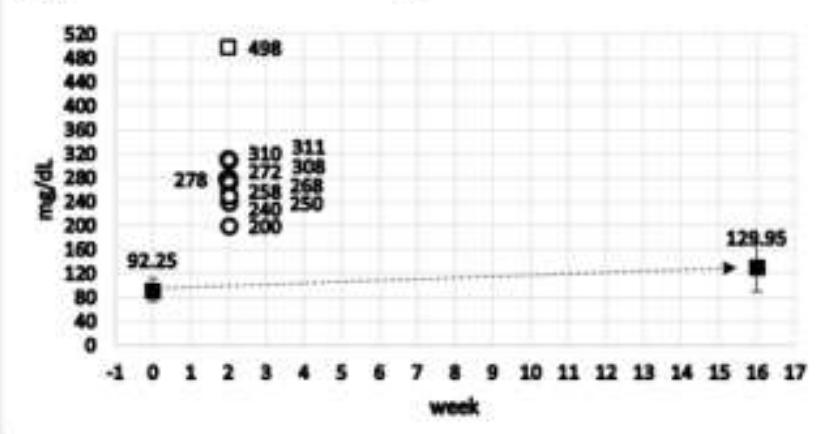

(c)

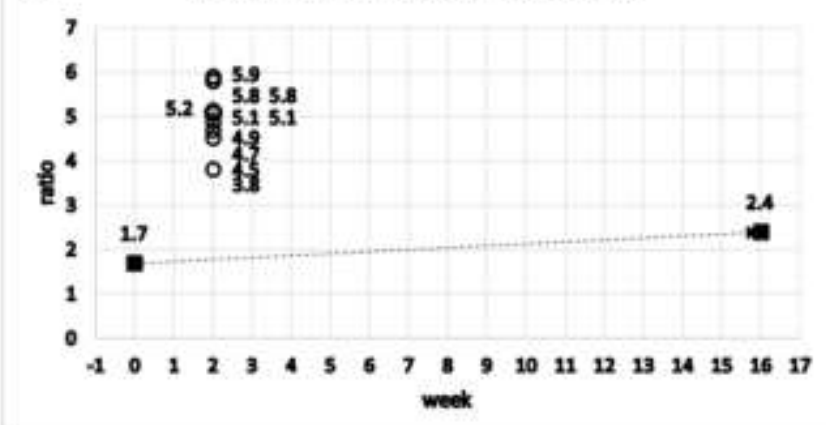

(e)

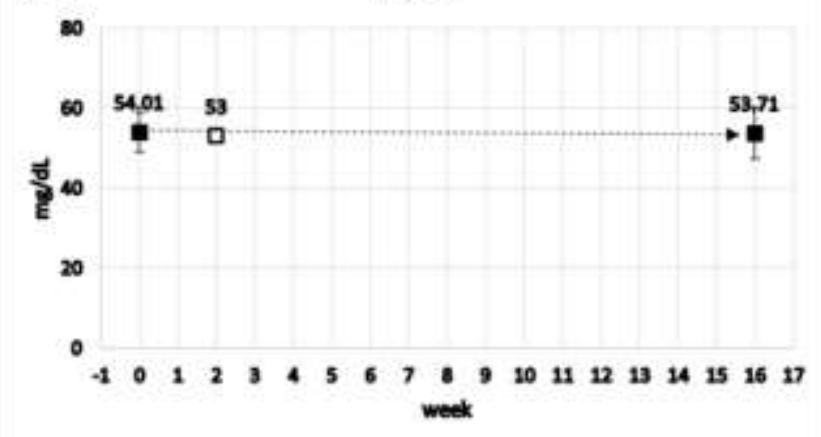

(b)
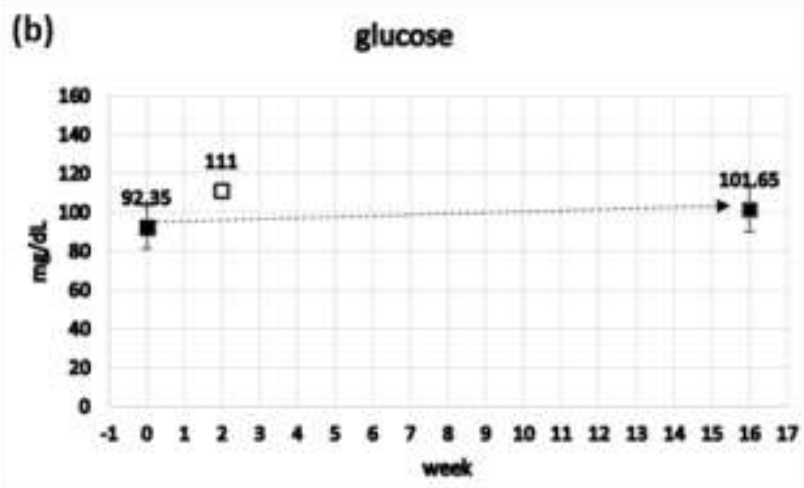

(d)

TC

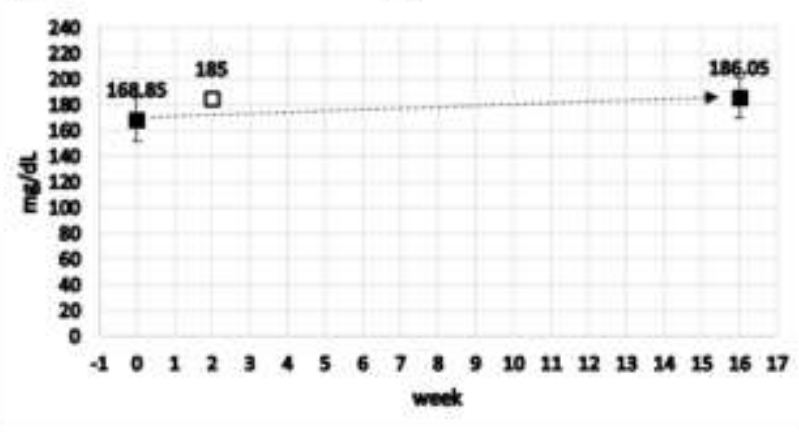

(f)

LDLC

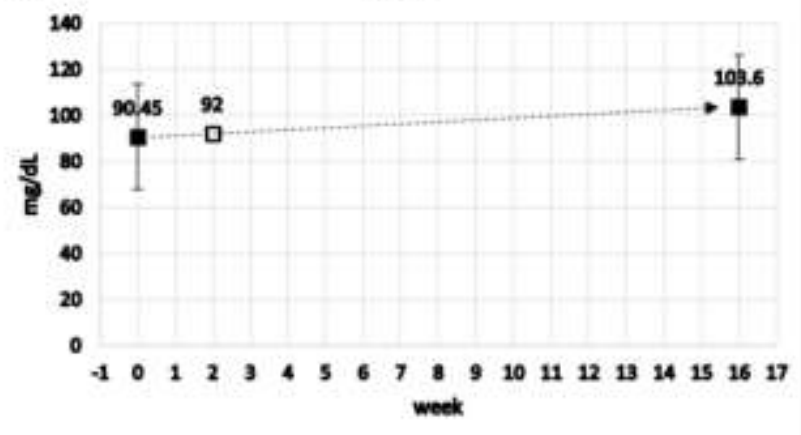

Figure 2: Comparison among lipid and glucose levels and TG/HDL-C ratios measured and calculated and those reported by Beyazyüz et al. [13]

Open squares $(\square)$ represent the lipid and glucose values measured in the blood examination for Mr. A in Hospital C on June $4^{\text {th }}, 2010$ after two weeks paroxetine treatment as summarized in Table 1. Open circles (o) represent the calculated TG values (TG-Cal) and TG-Cal/HDL-C ratios for Mr. A using the measured TG value (Table 1) and the formula reported by Hitze et al.[36], or the measured TC, HDL-C, and LDL-C values (Table 1) and nine formulas referred and reported by Dansethakul et al.[38] as summarized in Table 2. Filled squares (ロ) represent the lipid and glucose values measured before and after 16 weeks paroxetine treatment for 20 patients aged $27.5 \pm 3.1$ years without any metabolic comorbidity reported by Beyazyüz et al. [13] and the TG/HDL-C ratios calculated by the author. 
Table 1: Lipid and glucose levels measured in the blood of Mr. A at Hospital C at 15:56 on the $14^{\text {th }}$ day (June $\left.4^{\text {th }}, 2010\right)$ after the start of paroxetine treatment (May 22 ${ }^{\text {nd }}, 2010$ )

\begin{tabular}{c|c|c}
\hline Lipid or glucose & Measured value (mg/dL) & Normal range (mg/dL) \\
\hline Triglyceride (TG) & 498 & $50-150$ \\
Total cholesterol (TC) & 185 & $150-219$ \\
HDL-cholesterol (HDL-C) & 53 & $40-95$ \\
LDL-cholesterol (LDL-C) & 92 & $70-139$ \\
Non-fasting blood glucose & 111 & - \\
\hline
\end{tabular}

* Normal ranges were suggested in the blood test table by Hospital C. 
Table 2: TG-Cal values to estimate the fasting TG level $\left(\mathrm{TG}_{\text {fasting }}\right.$ ), paroxetine serum concentrations, and TG-Cal/HDL-C ratios calculated for Mr. A

\begin{tabular}{|c|c|c|c|c|c|}
\hline $\begin{array}{c}\text { Formula }^{* 1)} \text { to calculate TG } \\
\text { (TG-Cal) }\end{array}$ & $\begin{array}{l}\text { TG-Cal } \\
\text { mg/dL }\end{array}$ & $\begin{array}{l}\text { Par } \\
\text { (a) }\end{array}$ & $\begin{array}{l}\text { etine } \\
\text { mL } \\
\text { (b) }\end{array}$ & (c) & $\begin{array}{c}\text { TG-Cal/HDL-C } \\
\text { ratio }^{* 3)}\end{array}$ \\
\hline $\begin{array}{c}\mathrm{y}=0.59 \mathrm{x}-15.7^{* 1 \mathrm{a})} \\
\mathrm{y}=\mathrm{TG}_{\text {fasting }}(\mathrm{mg} / \mathrm{dL}) \\
\mathrm{x}=\mathrm{TG}_{\text {ppmax }}(\mathrm{mg} / \mathrm{dL})\end{array}$ & 278 & 334 & 300 & 287 & 5.2 \\
\hline $\begin{array}{l}\left.\mathrm{LDL}-\mathrm{C}=\mathrm{TC}-\mathrm{HDL}-\mathrm{C}-\mathrm{TG} / 5^{*} \mathrm{bb}\right) \\
\mathrm{TG}=5(\mathrm{TC}-\mathrm{HDL}-\mathrm{C}-\mathrm{LDL}-\mathrm{C})\end{array}$ & 200 & 208 & 174 & 161 & 3.8 \\
\hline $\begin{array}{l}\mathrm{LDL}-\mathrm{C}=0.9 \mathrm{TC}-0.9 \mathrm{TG} / 5-28 * 1 \mathrm{~b}) \\
\mathrm{TG}=5(0.9 \mathrm{TC}-28-\mathrm{LDL}-\mathrm{C}) / 0.9\end{array}$ & 258 & 302 , & 267 & 255 & 4.9 \\
\hline $\begin{array}{l}\left.\mathrm{LDL}-\mathrm{C}=\mathrm{TC}-\mathrm{HDL}-\mathrm{C}-\mathrm{TG} / 6^{* 1 \mathrm{~b}}\right) \\
\mathrm{TG}=6(\mathrm{TC}-\mathrm{HDL}-\mathrm{C}-\mathrm{LDL}-\mathrm{C})\end{array}$ & 240 & 273 & 238 & 226 & 4.5 \\
\hline $\begin{array}{l}\left.\text { LDL-C }=90 \% \text { Non-HDL-C }-10 \% \mathrm{TG}^{* 1 \mathrm{~b}}\right) \\
\mathrm{TG}=(0.9(\mathrm{TC}-\mathrm{HDL}-\mathrm{C})-\mathrm{LDL}-\mathrm{C}) / 0.1\end{array}$ & 268 & 318 & 284 & 271 & 5.1 \\
\hline $\begin{array}{c}\left.\mathrm{LDL}-\mathrm{C}(\mathrm{mmol} / \mathrm{L})=\mathrm{TC}-\mathrm{HDL}-\mathrm{C}-\mathrm{TG} / 3^{*} \mathrm{~b}\right) \\
\mathrm{LDL}-\mathrm{C}(\mathrm{mg} / \mathrm{dL})=\mathrm{TC}-\mathrm{HDL}-\mathrm{C}-\mathrm{TG} / 6.8 \\
\mathrm{TG}=6.8(\mathrm{TC}-\mathrm{HDL}-\mathrm{C}-\mathrm{LDL}-\mathrm{C})\end{array}$ & 272 & 324 & 290 & 277 & 5.1 \\
\hline $\begin{array}{l}\left.\mathrm{LDL}-\mathrm{C}=0.9629 \mathrm{TC}-0.8796 \mathrm{HDL}-\mathrm{C}-0.1272 \mathrm{TG}-0.1007^{* 1 \mathrm{~b}}\right) \\
\mathrm{TG}=(0.9629 \mathrm{TC}-0.8796 \mathrm{HDL}-\mathrm{C}-0.1007-\mathrm{LDL}-\mathrm{C}) / 0.1272\end{array}$ & 310 & 386 & 351 , & 339 & 5.8 \\
\hline $\begin{array}{l}\left.\mathrm{LDL}-\mathrm{C}=0.9656 \mathrm{TC}-0.8780 \mathrm{HDL}-\mathrm{C}-0.1278 \mathrm{TG}-0.7181^{* 1 \mathrm{~b}}\right) \\
\mathrm{TG}=(0.9656 \mathrm{TC}-0.8780 \mathrm{HDL}-\mathrm{C}-0.7181-\mathrm{LDL}-\mathrm{C}) / 0.1278\end{array}$ & 308 & 382 & 348 & 336 & 5.8 \\
\hline $\begin{array}{c}\left.\mathrm{LDL}-\mathrm{C}=0.9652 \mathrm{TC}-0.8757 \mathrm{HDL}-\mathrm{C}-0.1260 \mathrm{TG}-0.9675^{* 1 \mathrm{~b}}\right) \\
\mathrm{TG}=(0.9652 \mathrm{TC}-0.8757 \mathrm{HDL}-\mathrm{C}-0.9675-\mathrm{LDL}-\mathrm{C}) / 0.1260\end{array}$ & 311 & 387, & 353 & 340 & 5.9 \\
\hline $\begin{array}{c}\left.\mathrm{LDL}-\mathrm{C}=0.9875 \mathrm{TC}-0.9479 \mathrm{HDL}-\mathrm{C}-0.1801 \mathrm{TG}+4.4636{ }^{* 1 \mathrm{~b}}\right) \\
\mathrm{TG}=(0.9875 \mathrm{TC}-0.9479 \mathrm{HDL}-\mathrm{C}+4.4636-\mathrm{LDL}-\mathrm{C}) / 0.1801\end{array}$ & 250 & 289, & 254 & 242 & 4.7 \\
\hline Range & $200-311$ & \multicolumn{3}{|c|}{ 161-387 } & 3.8-5.9 \\
\hline
\end{tabular}

*1a) The TG-Cal value was calculated using the formula reported by Hitze et al. [36] and the measured value of TG (498 $\mathrm{mg} / \mathrm{dL})$ (Table 1).

*1b) The TG-Cal values were calculated using the nine formulas referred and reported by Dansethakul et al. [38] and the measured values of TC (185 mg/dL), HDL-C (53 mg/dL), and LDL-C (92 mg/dL) (Table 1).

*2a-c) Paroxetine serum concentrations (Paroxetine conc.) $(\mathrm{ng} / \mathrm{mL})$ were calculated using the ten TG-Cal values and three formulas (a) 75(TG-Cal - 71)/46.49, (b) 75(TG-Cal - 92.25)/46.49, and (c) 75(TG-Cal - 100)/46.49 based on the results reported by Fjukstad et al. [14] and on the assumption that Mr. A's TG level before paroxetine exposure was (a) $71 \mathrm{mg} / \mathrm{dL}$ [28], (b) $92.25 \mathrm{mg} / \mathrm{dL}$ [13], or (c) $100 \mathrm{mg} / \mathrm{dL}$, as described in the Results and Discussion section.

*3) TG-Cal/HDL-C ratios were calculated using the TG-Cal values and the measured value of HDL-C (53 mg/dL) (Table 1). 


\section{ACKNOWLEDGMENT}

I thank Dr. Lucire, Mr. Iwamoto, Mr. Koseki, Mr. Takahashi, and Mr. Shionaka for their contributions and considerations.

\section{REFERENCES}

[1] PAXIL (paroxetine hydrochloride) Prescribing information https://www.accessdata.fda.gov/drugsatfda_docs/label/2008/020031s060,020936s037,020710s024lbl.pdf http://www.info.pmda.go.jp/go/pack/1179041F1025_2_35/ (in a Japanized version)

[2] Noury JL, Nardob JM, Healya D, Jureidinic J, Ravenc M, Tufanaruc C, Abi-Jaouded E, Study 329 continuation phase: Safety and efficacy of paroxetine and imipramine in extended treatment of adolescent major depression. International Journal of Risk \& Safety in Medicine. 2016;28:143-161.

[3] Nakagawa EK, Two Simultaneous Increases Observed both in Youth Suicide Rates and Antidepressant Sales Amounts in Japan, 2002-2009: A Possible Link between Youth Suicides and Uses of Antidepressants. Asian Journal of Pharmacy, Nursing and Medical Sciences. 2015 April;3(2):33-39.

[4] Lucire Y, Crotty C, Antidepressant-induced akathisia-related homicides associated with diminishing mutations in metabolizing genes of the CYP450 family. Pharmgenomics Pers Med. 2011;4:65-81.

[5] Hiemke C, Baumann P, Bergemann N, Conca A, Dietmaier O, Egberts K, Fric M, Gerlach M, Greiner C, Gründer G, Haen E, Havemann-Reinecke U, Jaquenoud Sirot E, Kirchherr H, Laux G, Lutz UC, Messer T, Müller MJ, Pfuhlmann B, Rambeck B, Riederer P, Schoppek B, Stingl J, Uhr M, Ulrich S, Waschgler R, Zernig G. AGNP Consensus Guidelines for Therapeutic Drug Monitoring in Psychiatry: Update 2011. Pharmacopsychiatry. 2011;44:195-235.

[6] Tomita T, Yasui-Furukori N, Nakagami T, Tsuchimine S, Ishioka M, Kaneda A, Nakamura K, Kaneko S. Therapeutic reference range for plasma concentrations of paroxetine in patients with major depressive disorders. 2014 Aug;36(4):480-5.

[7] Kreilgaard M, Smith DG, Brennum LT, Sánchez C. Prediction of clinical response based on pharmacokinetic/pharmacodynamic models of 5-hydroxytryptamine reuptake inhibitors in mice. $\mathrm{Br} \mathrm{J}$ Pharmacol. 2008 Sep;155(2):276-84.

[8] Hegerl U, Bottlender R, Gallinat J, Kuss HJ, Ackenheil M, Möller HJ. The serotonin syndrome scale: first results on validity. Eur Arch Psychiatry Clin Neurosci. 1998;248(2):96-103.

[9] Coupland C, Hill T, Morriss R, Arthur A, Moore M, Hippisley-Cox J. Antidepressant use and risk of suicide and attempted suicide or self-harm in people aged 20 to 64: cohort study using a primary care database. BMJ. 2015 Feb 18;350:h517.

[10] Valenstein M, Kim HM, Ganoczy D, Eisenberg D, Pfeiffer PN, Downing K, Hoggatt K, Ilgen M, Austin KL, Zivin K, Blow FC, McCarthy JF. Antidepressant Agents and Suicide Death among US Department of Veterans Affairs Patients in Depression Treatment. J Clin Psychopharmacol. 2012 Jun;32(3):346-53.

[11] Kim HM, Zivin K, Ganoczy D, Pfeiffer P, Hoggatt K, McCarthy JF, Downing K, Valenstein M. Predictors of alternative antidepressant agent initiation among U. S. veterans diagnosed with depression. 2010 Oct;19(10):1049-56.

[12] Ilgen MA, Bohnert AS, Ignacio RV, McCarthy JF, Valenstein MM, Kim HM, Blow FC. Psychiatric diagnoses and risk of suicide in veterans. Arch Gen Psychiatry. 2010 Nov;67(11):1152-8.

[13] Beyazyüz M, Albayrak Y, Eğilmez OB, Albayrak N, Beyazyüz E. Relationship between SSRIs and Metabolic Syndrome Abnormalities in Patients with Generalized Anxiety Disorder: A Prospective Study. Psychiatry Investig. 2013 Jun;10(2):148-54.

[14] Fjukstad KK, Engum A, Lydersen S, Dieset I, Steen NE, Andreassen OA, Spigset O. Metabolic Abnormalities Related to Treatment with Selective Serotonin Reuptake Inhibitors in Patients with Schizophrenia or Bipolar Disorder. J Clin Psychopharmacol. 2016 Dec;36(6):615-620.

[15] Levkovitz Y, Ben-Shushan G, Hershkovitz A, Isaac R, Gil-Ad I, Shvartsman D, Ronen D, Weizman A, Zick Y. Antidepressants induce cellular insulin resistance by activation of IRS-1 kinases. Mol Cell Neurosci. 2007 Nov;36(3):305-12.

[16] Isaac R, Boura-Halfon S, Gurevitch D, Shainskaya A, Levkovitz Y, Zick Y. Selective serotonin reuptake inhibitors (SSRIs) inhibit insulin secretion and action in pancreatic $\beta$ cells. J Biol Chem. 2013 Feb 22;288(8):5682-93. J Biol Chem. 2018 Mar 23;293(12):4577-78. 
[17] Matthews DR, Hosker JP, Rudenski AS, Naylor BA, Treacher DF, Turner RC. Homeostasis model assessment: insulin resistance and beta-cell function from fasting plasma glucose and insulin concentrations in man. Diabetologia. $1985 \mathrm{Jul} ; 28(7): 412-9$.

[18] Fujii C, Kawai T, Azuma K, Oguma Y, Katsukawa F, Hirose H, Tanaka K, Meguro S, Matsumoto H, Itoh H. Relationships between Composition of Major Fatty Acids and Fat Distribution and Insulin Resistance in Japanese. J Diabetes Res. 2017;2017:1567467.

[19] Yamada C, Mitsuhashi T, Hiratsuka N, Inabe F, Araida N, Takahashi E. Optimal reference interval for homeostasis model assessment of insulin resistance in a Japanese population. J Diabetes Investig. 2011 Oct 7;2(5):373-6.

[20] Tabák AG, Jokela M, Akbaraly TN, Brunner EJ, Kivimäki M, Witte DR. Trajectories of glycaemia, insulin sensitivity, and insulin secretion before diagnosis of type 2 diabetes: an analysis from the Whitehall II study. Lancet. 2009 Jun 27;373(9682):2215-21.

[21] Reaven GM, Insulin resistance and compensatory hyperinsulinemia: the linchpin between obesity and cardiovascular disease. CMR eJournal Official Journal of the International Chair on Cardiometabolic Risk. 2008 May; 1(2): 4-10.

[22] McLaughlin T, Reaven G, Abbasi F, Lamendola C, Saad M, Waters D, Simon J, Krauss RM. Is there a simple way to identify insulin-resistant individuals at increased risk of cardiovascular disease? Am J Cardiol. 2005 Aug 1;96(3):399-404.

[23] Salazar MR, Carbajal HA, Espeche WG, Leiva Sisnieguez CE, March CE, Balbín E, Dulbecco CA, Aizpurúa M, Marillet AG, Reaven GM. Comparison of the abilities of the plasma triglyceride/high-density lipoprotein cholesterol ratio and the metabolic syndrome to identify insulin resistance. Diab Vasc Dis Res. 2013 Jul;10(4):346-52.

[24] Murguía-Romero M, Jiménez-Flores JR, Sigrist-Flores SC, Espinoza-Camacho MA, Jiménez-Morales M, Piña E, Méndez-Cruz AR, Villalobos-Molina R, Reaven GM. Plasma triglyceride/HDL-cholesterol ratio, insulin resistance, and cardiometabolic risk in young adults. J Lipid Res. 2013 Oct;54(10):2795-9.

[25] Shin HG, Kim YK, Kim YH, Jung YH, Kang HC. The Relationship between the Triglyceride to High-Density Lipoprotein Cholesterol Ratio and Metabolic Syndrome. Korean J Fam Med. 2017 Nov;38(6):352-357.

[26] Samant P, Chavan P, Rai S. TG/HDL-C Ratio: A Surrogate Marker of Insulin Resistance in Patients with Metabolic Syndrome. MGM J Med Sci 2014;1(1):18-21.

[27] Ray S, Talukdar A, Sonthalia N, Saha M, Kundu S, Khanra D. Guha S, Basu AK, Mukheriee A, Ray D. Serum lipoprotein ratios as markers of insulin resistance: A study among nondiabetic acute coronary syndrome patients with impaired fasting glucose. Indian J Med Res. 2015 Jan; 141(1): 62-67.

[28] Kathiresan S, Otvos JD, Sullivan LM, Keyes MJ, Schaefer EJ, Wilson PW, D'Agostino RB, Vasan RS, Robins SJ. Increased small low-density lipoprotein particle number: a prominent feature of the metabolic syndrome in the Framingham Heart Study. Circulation. 2006 Jan 3;113(1):20-9.

[29] Lewis GF, Rader DJ. New insights into the regulation of HDL metabolism and reverse cholesterol transport. Circ Res. 2005 Jun 24;96(12):1221-32.

[30] Lamarche B, Uffelman KD, Carpentier A, Cohn JS, Steiner G, Barrett PH, Lewis GF. Triglyceride enrichment of HDL enhances in vivo metabolic clearance of HDL apo A-I in healthy men. J Clin Invest. 1999 Apr;103(8):1191-9.

[31] Greene DJ, Skeggs JW, Morton RE. Elevated triglyceride content diminishes the capacity of high density lipoprotein to deliver cholesteryl esters via the scavenger receptor class B type I (SR-BI). J Biol Chem. 2001 Feb 16;276(7):4804-11.

[32] Vega GL, Gylling H, Nichols AV, Grundy SM. Evaluation of a method for study of kinetics of autologous apolipoprotein A-I. J Lipid Res. 1991 May;32(5):867-75.

[33] Ginsberg HN, Ngai C, Wang XJ, Ramakrishnan R. Increased production rates of LDL are common in individuals with low plasma levels of HDL cholesterol, independent of plasma triglyceride concentrations. Arterioscler Thromb. 1993 Jun;13(6):842-51.

[34] Rader DJ, Castro G, Zech LA, Fruchart JC, Brewer HB Jr. In vivo metabolism of apolipoprotein A-I on high density lipoprotein particles LpA-I and LpA-I, A-II. J Lipid Res. 1991 Nov;32(11):1849-59.

[35] Franceschini G, Moreno Y, Apebe P, Calabresi L, Gatti E, Noè D, de Fabiani E, Zoppi F, Sirtori CR. Alterations in high-density lipoprotein subfractions during postprandial lipidaemia induced by fat with and without ethanol. Clin Sci (Lond). 1988 Aug;75(2):135-42.

[36] Hitze B, Rubin D, Helwig U, Schrezenmeir J, Bosy-Westphal A, Müller MJ. Postprandial triglyceride response in men: role of overweight, abdominal fat and nutrition. Obes Facts. 2008;1(1):45-51. 
[37] Mora S, Rifai N, Buring JE, Ridker PM. Fasting compared with nonfasting lipids and apolipoproteins for predicting incident cardiovascular events. Circulation. 2008 Sep 2;118(10):993-1001.

[38] Dansethakul P, Thapanathamchai L, Saichanma S, Worachartcheewan A, Pidetcha P. Determining a new formula for calculating low-density lipoprotein cholesterol: data mining approach. EXCLI J. 2015 Mar 26;14:478-83.

[39] Friedewald WT, Levy RI, Fredrickson DS. Estimation of the concentration of low-density lipoprotein cholesterol in plasma, without use of the preparative ultracentrifuge. Clin Chem. 1972 Jun;18(6):499-502.

[40] Murakata Y, Fujimaki T, Yamada Y. Age-related changes in clinical parameters and their associations with common complex diseases. Biomed Rep. 2015 Nov;3(6):767-77.

[41] Lewis RJ, Kemp PM, Johnson RD. Paroxetine in postmortem fluids and tissues from nine aviation accident victims. J Anal Toxicol. 2015 Oct;39(8):637-41.

[42] Yin J, Li M, Xu L, Wang Y, Cheng H, Zhao X, Mi J. Insulin resistance determined by Homeostasis Model Assessment (HOMA) and associations with metabolic syndrome among Chinese children and teenagers. Diabetol Metab Syndr. 2013 Nov 15;5(1):71.

[43] Heydorn WE. Paroxetine: a review of its pharmacology, pharmacokinetics and utility in the treatment of a variety of psychiatric disorders. Expert Opin Investig Drugs. 1999 Apr;8(4):417-41.

[44] Toutain PL, Bousquet-Mélou A. Plasma terminal half-life. J Vet Pharmacol Ther. 2004 Dec;27(6):427-39.

[45] Bertelsen KM, Venkatakrishnan K, Von Moltke LL, Obach RS, Greenblatt DJ. Apparent mechanism-based inhibition of human CYP2D6 in vitro by paroxetine: comparison with fluoxetine and quinidine. Drug Metab Dispos. 2003 Mar;31(3):289-93.

[46] Jornil J, Jensen KG, Larsen F, Linnet K. Identification of cytochrome P450 isoforms involved in the metabolism of paroxetine and estimation of their importance for human paroxetine metabolism using a population-based simulator. Drug Metab Dispos. 2010 Mar;38(3):376-85.

[47] Zhao SX, Dalvie DK, Kelly JM, Soglia JR, Frederick KS, Smith EB, Obach RS, Kalgutkar AS. NADPH-dependent covalent binding of $[3 \mathrm{H}]$ paroxetine to human liver microsomes and $\mathrm{S}-9$ fractions: identification of an electrophilic quinone metabolite of paroxetine. Chem Res Toxicol. 2007 Nov;20(11):1649-57.

[48] Uttamsingh V, Gallegos R, Liu JF, Harbeson SL, Bridson GW, Cheng C, Wells DS, Graham PB, Zelle R, Tung R. Altering metabolic profiles of drugs by precision deuteration: reducing mechanism-based inhibition of CYP2D6 by paroxetine. J Pharmacol Exp Ther. 2015 Jul;354(1):43-54.

[49] Lam YW, Gaedigk A, Ereshefsky L, Alfaro CL, Simpson J. CYP2D6 inhibition by selective serotonin reuptake inhibitors: analysis of achievable steady-state plasma concentrations and the effect of ultrarapid metabolism at CYP2D6. Pharmacotherapy. 2002 Aug;22(8):1001-6.

[50] Livezey M, Nagy LD, Diffenderfer LE, Arthur EJ, Hsi DJ, Holton JM, Furge LL. Molecular analysis and modeling of inactivation of human CYP2D6 by four mechanism based inactivators. Drug Metab Lett. 2012 Mar;6(1):7-14.

[51] Mann A, Miksys SL, Gaedigk A, Kish SJ, Mash DC, Tyndale RF. The neuroprotective enzyme CYP2D6 increases in the brain with age and is lower in Parkinson's disease patients. Neurobiol Aging. 2012 Sep;33(9):2160-71.

[52] Ueda M, Hirokane G, Morita S, Okawa M, Watanabe T, Akiyama K, Shimoda K. The impact of CYP2D6 genotypes on the plasma concentration of paroxetine in Japanese psychiatric patients. Prog Neuropsychopharmacol Biol Psychiatry. 2006 May;30(3):486-91.

[53] Ramamoorthy Y, Tyndale RF, Sellers EM. Cytochrome P450 2D6.1 and cytochrome P450 2D6.10 differ in catalytic activity for multiple substrates. Pharmacogenetics. 2001 Aug;11(6):477-87.

[54] Feng Y, Pollock BG, Ferrell RE, Kimak MA, Reynolds CF 3rd, Bies RR. Paroxetine: population pharmacokinetic analysis in late-life depression using sparse concentration sampling. Br J Clin Pharmacol. 2006 May;61(5):558-69.

[55] Sakuyama K, Sasaki T, Ujiie S, Obata K, Mizugaki M, Ishikawa M, Hiratsuka M. Functional characterization of 17 CYP2D6 allelic variants (CYP2D6.2, 10, 14A-B, 18, 27, 36, 39, 47-51, 53-55, and 57). Drug Metab Dispos. 2008 Dec;36(12):2460-7.

[56] District Court http://www.courts.go.jp/osaka/index.html Judgment, June $7^{\text {th }}$, 2016; heisei25nen(wa)dai765gou, original decision (full-text in Japanese available for inspection on application in the court).

[57] High Court http://www.courts.go.jp/osaka-h/index.html Judgement, Jan 27 ${ }^{\text {th }}$, 2017; heisei28nen(ne)dai1973gou, second court decision (full-text in Japanese available for inspection on application in the court).

[58] Williams G, Ellison L, Duty to warn and protect. In B. Erford (Ed.) The American Counseling Association's Encyclopedia of Counseling. Alexandria, VA: American Counseling Association. 2009:163-5.

[59] Kraus JE, Horrigan JP, Carpenter DJ, Fong R, Barrett PS, Davies JT. Clinical features of patients with treatmentemergent suicidal behavior following initiation of paroxetine therapy. J Affect Disord. 2010 Jan;120(1-3):40-7. 
[60] Donovan S, Clayton A, Beeharry M, Jones S, Kirk C, Waters K, Gardner D, Faulding J, Madeley R. Deliberate selfharm and antidepressant drugs. Investigation of a possible link. Br J Psychiatry. 2000 Dec;177:551-6.

[61] Khan A, Khan S, Kolts R, Brown WA. Suicide rates in clinical trials of SSRIs, other antidepressants, and placebo: analysis of FDA reports. Am J Psychiatry. 2003 Apr;160(4):790-2. 